\title{
ANATOMOPOESIA - \\ UMA PROPOSTA PEDAGÓGICA DE INTEGRAÇÃO DOS SABERES
}

Vanessa Matos ${ }^{\mathrm{i}}$

\begin{abstract}
Resumo: $\mathrm{O}$ artigo é relato da experiência da pesquisa - AnatomoPoesia - sediada na Faculdade Angel Vianna/RJ, desde 2017, dentro da disciplina Anatomia Aplicada à Dança, lecionada pela autora. O objetivo geral deste artigo é apresentar a pesquisa AnatomoPoesia. Os objetivos específicos: contextualizar a fonte inspiradora da pesquisa - a Mestre Angel Vianna e sua metodologia; conceituar o que é AnatomoPoesia; refletir junto aos marcos teóricos sobre os conceitos que alicerçam a pesquisa.
\end{abstract}

Palavras-chave: Metodologia Angel Vianna; Educação pelo Movimento; Anatomia Humana; AnatomoPoesia.

\section{ANATOMOPOETRY - A PEDAGOGICAL PROPOSAL FOR THE INTEGRATION OF KNOWLEDGE}

\begin{abstract}
The article is an experience report about the research - Anatomopoetry - based in Angel Vianna College/RJ (Brazil), since 2017, with in the discipline Anatomya plied to dance, lectured by Vanessa Matos. The aim of this study is to presentthe AnatomoPoetry research. Specificaims: Contextualize the inspiring source of the research - the Master Angel Vianna and her Methodology. Define what AnatomoPoetryis. Reflect along with the theor etical frame works on the concept sthatunder lie this research.
\end{abstract}

Key-words: Angel Vianna Methodology; MovementEducation; HumanAnatomy; AnatomoPoetry.

\section{Introdução}

A reflexão é um processo de conhecer como conhecemos, um ato de nos voltarmos sobre nós mesmos, a única oportunidade que temos de descobrir nossas cegueiras e de reconhecer que as certezas e os conhecimentos dos outros são, respectivamente tão nebulosos e tênues quanto os nossos (MATURANA e VARELA, 2001, p.67).

AnatomoPoesia é neologismo criado em 2017 por mim, Vanessa Matos, professora/pesquisadora atuante na Faculdade Angel Vianna/RJ (FAV/RJ), para denominar minha persquisa, desenvolvida desde então, semanalmente, durante as aulas de Anatomia Aplicada à Dança, na faculdade citada. 
A pesquisa tem o objetivo geral de integrar os saberes entre ciência, arte, natureza e consciência corporal, na prática dos discentes voltada ao conhecimento e reconhecimento da estrutura e função do próprio corpo, por meio de aulas teóricas de anatomia, com materiais didáticos clássicos, somados a vivências em "Plataformas Pedagógicas Sensitivas".

As Plataformas Pedagógicas Sensitivas são espaços inventados na sala de aula, para sensorializar o conteúdo teórico das histórias científicas, convidando o sujeito a reconhecer a teoria científica na prática artística de si mesmo e refletir sobre Conhecer como Conhecemos.

A ideia de refletir sobre conhecer como conhecemos, assim como a possibilidade de enxergar o corpo humano como a fonte biológica produzida e produtora de si, da natureza, da sociedade, da cultura e da política, foi inspirada em dois pensadores chilenos, muito importantes para a fundamentação teórica da pesquisa, Maturana e Varela (2001).

A partir desta reflexão, podemos descobrir o quanto nós seres humanos, independentemente dos títulos que nos definem, temos certezas e conhecimentos por muitas vezes nebulosos, tênues, impermanentes e passíveis de desconstrução, a qualquer momento.

Com esse aceno, os autores citados revelam a incomensurável fragilidade de todas as nossas certezas e, como pode vir a ser libertador descortinar essa parte da nossa condição humana que nos torna frágeis e vulneráveis. Como é necessário reconhecermos estes aspectos da nossa humanidade e neles as cegueiras e limites sobre o que sabemos. Só o fato de lembrarmos uns aos outros que o que sabemos é ínfimo, perto do que não sabemos, pode vir a ser a possibilidade da nossa própria reinvenção.

Por isso, ao refletir sobre conhecer como conhecemos nos damos conta da necessidade de rever os vistos e redizer os ditos na educação do século XXI, pois os saberes não sabem tudo e, sim, estão em movimento, acontecendo aqui e agora, entre possibilidades aleatórias, assim como programadas de acordo com os poderes vigentes. Como podemos observar na citação abaixo:

Será que, se decidíssemos citar pelo menos alguns exemplos das fronteiras do conhecimento em que a ciência tenta atualmente progredir, isso não poderia dar a impressão de que esta ciência está evoluindo, que ela é viva, graças aos pesquisadores em pleno trabalho, em vez de apresentá-la como um conjunto de conhecimentos escolares fixos destinados às provas de avaliação? (MORRIN apud BALIBAR, 2002, p.67)

No espaço/tempo das possibilidades, o que podemos escolher realizar como educadores do século XXI? Será possível integrar teorias e práticas de ensino-aprendizagem que conciliem a educação, pelo pensamento do corpo, à educação, pelo movimento do corpo? De acordo com a professora da Unicamp Márcia Strazzacappa (2001) o individuo age no mundo através do seu 
corpo, mais especificamente através do movimento. A professora Strazzacappa (2001), refletindo em seu artigo sobre o pensamento do professor-pesquisador italiano Ciro Giordano Bruni (1931), coloca pertinentemente que virou regra segmentar comportamentos diferenciados para o corpo, nas aulas de arte e nas aulas de ciência.

Nas aulas de artes o corpo pode ficar descontraído e vivenciar práticas lúdicas, pois não é necessário que se trate a arte como uma disciplina séria. Já nas aulas de ciências, o comportamento esperado dos corpos é que eles permaneçam duros, rígidos, imóveis e sentados uns atrás dos outros em silêncio, prestando atenção, pois essa é a postura que se espera durante uma disciplina considerada séria.

Esse é o cenário do sistema educacional de fragmentação e abuso de poder no qual a educação está formatada, nos levando a produção de estigmas, dissociação e fragmentação, ao reforçarmos nas nossas práticas docentes que a arte é o espaço possível da desordem e a ciência o espaço possível da ordem. Sem prestar atenção à dialógica como elemento de integração. Cito Morin (2002):

Há uma espécie de luta entre o princípio da ordem e um princípio de desordem, mas também uma espécie de cooperação entre ambos, cooperação da qual nasce uma ideia ausente na física clássica, que é a de organização. $\mathrm{O}$ que devemos considerar é o jogo entre a ordem, a desordem e a organização. Chamo este jogo de dialógica, pois essas noções que se repelem entre si, que são antagônicas, que são mesmo contraditórias, são necessariamente complementares para conceber nosso universo, seus fenômenos organizados e, ao mesmo tempo seus fenômenos destruidores. (MORIN, 2002, p.561-562)

Para tantos anos de repetição do modelo educacional que fragmenta, colocando a ordem e a desordem como opostos, evoco a possibilidade de integrar os saberes e pensar que a integração é o que surge do sistema de fragmentação, podendo corroborar com a conciliação entre a educação pelo pensamento do corpo (a ordem), e a educaçao pelo movimento do corpo (a desordem), desenvolvendo de acordo com Morin (2002) a organização de ambas, como dialógicas necessárias para a educação do século XXI.

O conceito de integrar os saberes foi inspirado no estudo de um dos marcos teóricos desta pesquisa - A religação dos saberes - de Morin (2002) - e vem sendo aprofundado ao longo dos encontros com Teixeira (2008), Imbassaí (1996), Gardner (1994), Strazzacappa (2001), Maturana (2001), Vianna (2005), Saldanha (2009), Lent (2010), Mancuso (2019) e Mele (2019). Estes pensadores e pensadoras são os escolhidos para fundamentar as ideias que alicerçam o desenvolvimento desse texto, relato de experiência.

Revista Interinstitucional Artes de Educar. Rio de Janeiro, V. 5, N.3- pág. 695-725 set-dez de 2019: "Educação: Corpo em movimento." - DOI: 10.12957/riae.2019.46727 


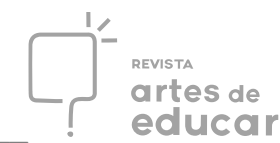

A possibilidade real - de integrar conscientemente - teoria e prática, ciência e arte, corpo e natureza - foi fertilizada ao longo dos anos de estudos na Faculdade Angel Vianna e começou a ser desenvolvida nas pesquisas que realizei, concluindo, em 2011, a Especialização em Metodologia Angel Vianna na FAV/RJ, com a monografia - Anatomias: uma proposta de integração da Metodologia Angel Vianna ao ensino-aprendizagem da anatomia humana.

A reflexão sobre a viabilidade dessa proposta foi se fortalecendo e se tornou prática em 2015, quando materializei minhas idéias dentro do Curso Livre da Escola e Faculdade Angel Vianna/RJ (EFAV/RJ) na forma das aulas semanais abertas ao público, denominadas Anatomia Experimentada.

Em 2017, a convite da própria Angel Vianna e sua vice-diretora Marcia Feijó, assumi a disciplina Anatomia Aplicada à Dança, na FAV/RJ e comecei a desenvolver a prática semanal de integração dos saberes entre ciência e arte visando a possibilidade de educação científicoartística, que denominei AnatomoPoesia.

O presente artigo é o relato da experiência da pesquisa AnatomoPoesia - experimentada ao longo desses últimos dois anos na FAV/RJ. A narrativa se desdobra no seguinte roteiro: Breve Historiografia da Mestre Angel Vianna; A Metodologia Angel Vianna; AnatomoPoesia: A Natureza; A Ciência - Corpo Somestésico, Sentir, Perceber, Mover; A Arte - Plataformas Pedagógicas Sensitivas; Fotografias; Considerações Finais.

\section{Breve Historiografia da Mestre Angel Vianna}

Na entrevista dada a Botelho et al, Revista do Centro de Pesquisa em Formação do Sesc São Paulo (2016, p.270), Angel afirma: Eu acredito no que escolhi para fazer e fiz com muito desejo. Segundo os entrevistadores - Maria Ângela Abras Vianna (1928) - Angel Vianna - é uma das maiores artistas brasileiras (...) que continua trabalhando intensamente pela dança no Brasil. Reafirma Mamberti (2009):

Bailarina, coreógrafa, professora e pesquisadora, Angel Vianna é uma referência (...) Seus estudos sobre a sensibilização do corpo e a conscientização do movimento não se tornaram essenciais somente na formação de bailarinos e atores; também podem ser aplicados em processos terapêuticos, de reabilitação motora e em áreas ligadas à saúde (...) Educadora que estimula a busca da subjetividade de cada um de seus alunos. Ao estender a prática da dança a todos os que quiserem experimentá-la, Angel Vianna 
abriu espaço para a aceitação das múltiplas estéticas do corpo. (MAMBERTI, 2009, p.15)

Maria Ângela Abras Vianna - Angel Vianna - nasceu em Belo Horizonte, em 1928. Iniciou seus estudos de balé clássico em 1940 e oito anos depois passou a integrar o Balé de Minas Gerais. Em 1953, Angel formou-se em Belas Artes e no ano seguinte descobriu o corpo - como professora de dança para crianças.

Em 1955, iniciou, juntamente com seu marido Klauss Vianna, pesquisas e estudos da anatomia humana. Começaram a frequentar aulas de Anatomia, Fisiologia e Cinesiologia na Faculdade de Odontologia, em Belo Horizonte.

De acordo com Angel na entrevista à revista:

Nós estudamos muita anatomia, nós ficamos interessados em entender como nós poderíamos ajudar o trabalho corporal de uma criança. Mas em Minas havia poucos professores de anatomia, mas eu fui parar na odontologia, que tinha um professor que me aceitou dar aula, para mim e para o Klauss. Ele era da odontologia e eu da dança, mas era preciso entender o que é o corpo humano. Eu precisava entender como funciona esse corpo para eu poder utilizá-lo. Daí surgiu a parte de anatomia das escolas de dança. Eu e o Klauss decidimos então ensinar às pessoas a anatomia e como usar as articulações. $\mathrm{E}$ com isso a anatomia hoje faz parte das artes. (BOTELHO, 2016, p.275)

Desenvolvendo um olhar mais orgânico sobre o ensino da dança, introduziram, inspirados no Yoga, trabalhos de apoio no chão, além da Percepção Musical, como elementos de atenção, concentração, ritmo e harmonia. Em 1957 fundaram o Ballet Klauss Vianna. Em 1962 Angel Vianna realizou a direção corporal da peça O pagador de promessas. De 1962 a 1964, lecionou na Universidade Federal da Bahia, lá introduzindo a disciplina Balé Clássico.

A partir de 1964 o casal foi precursor da expressão corporal no Brasil, que haviam estudado na argentina, com Patrícia Stokoe (1919-1996). Angel e Klauss enriqueceram a cena teatral com esta arte que manifesta a consciência do corpo nos seus gestos, posturas e subjetividade. $\mathrm{O}$ corpo passou a fazer parte do teatro brasileiro como matéria a ser estudada, pensada, elaborada e desenvolvida, em partituras corporais aplicadas à cena, com a mesma relevância da voz e do texto.

A partir de então, Angel Vianna trabalhou como preparadora corporal em inúmeras peças teatrais no cenário carioca, influenciando e enriquecendo a dinâmica e a expressividade corporal dos atores. Em 1972 foi aos Estados Unidos, tendo oportunidade de conhecer 
autoridades na Educação Somática do Corpo pelo Movimento, como Gerda Alexander, criadora da Eutonia, Moshe Feldenkrais, Alvin Nikolai e Katie Grant, Zena Rommet, Merce Cunningham. Também conheceu a técnica de Joseph Pilates.

Em 1975 fundou, no Rio de Janeiro, o Centro de Pesquisas Corporais, e no ano seguinte, o Teatro do Movimento, para, em seguida, formar com Klauss Vianna e Tereza d'Aquino, o primeiro grupo de Formação Profissional em Expressão Corporal. Dois anos depois, criou o Espaço Novo - Centro de Estudos do Movimento e Artes - atual Escola e Faculdade Angel Vianna.

Em 1983, o MEC reconheceu o Centro de Estudos do Movimento e Arte. Dois anos depois aconteceu a primeira formatura em nível de segundo grau técnico da Escola Angel Vianna, no curso de Formação de Bailarino, Recuperação Motora e Terapia através da Dança.

Nos anos 1990 a expressão corporal tornou-se disciplina oficial nos cursos de dança e de teatro no Brasil. Segundo Imbassaí (1996, p. 129): Na mesma década, a Expressão Corporal consubstanciou a formação do Método Angel Vianna de Conscientização do Movimento e Jogos Corporais.

Desde 2001 a Faculdade Angel Vianna oferece bacharelado e licenciatura em dança. Em convênio com a Universidade Federal da Bahia, abriu o curso de pós-graduação lato sensu, de Estudos Contemporâneos em Dança. Hoje oferece os seguintes cursos de pós-graduação: Metodologia Angel Vianna; Terapia através do Movimento; Corpo e Subjetivação; Sistema Laban/ Bartenieff; Corpo, Diferença e Educação; Formação de Preparador Corporal nas Artes Cênicas.

O método de Angel Vianna considera o sentimento e o movimento do corpo vivo no seu constante processo de ensino-aprendizagem, tomando como referência o corpo singular de cada sujeito simultaneamente sensível e movente; como as nuvens, sempre capaz de se transformar. Daí surgiu a sua célebre frase registrada por Saldanha (2009, p.89) Gente é como nuvem, sempre se transforma.

\section{Metodologia Angel Vianna (MAV)}

O trabalho corporal como desenvolvido por Angel Vianna pode ser visto como uma elaboração da alta complexidade do ser humano (...) do ponto de vista de uma teoria do conhecimento, o trabalho de Angel Vianna consiste na construção de um sofisticado sistema conceitual e de ações, que tenta mapear ontologicamente o sistema corpo. (VIEIRA, 2009, p. 33) 


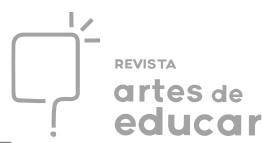

A Metodologia Angel Vianna - MAV é uma proposta de estudo-aprendizagem do corpo no corpo, por meio do desenvolvimento da consciência corporal e do movimento do ser humano. Entendemos que a "consciência corporal", a "conscientização corporal", a "conscientização do movimento e jogos lúdicos", são diferentes nomes para a mesma composição do trabalho de décadas das pesquisas práticas de Angel Vianna.

Portanto as denominações acima citadas são maneiras diferentes de descrever uma mesma prática corporal, atualmente contidas na denominação Metodologia Angel Vianna (MAV). De fato os princípios considerados são os mesmos, porém, como se trata de uma metodologia "viva", os nomes foram mudando ao longo do tempo das experiências. Também a singularidade de cada professor é considerada. Por isso os princípios básicos preconizados pela Mestre orientam as aulas, mas deixam espaço para que cada professor imprima seu próprio cunho.

O cerne da MAV é a consciência corporal do movimento e a dança:

Durante o processo de trabalho com o Método de Angel Vianna, o aluno pode perceber que conforme altera sua estrutura abrindo os espaços articulares, mais a sua forma de pensar vai mudando. Com a expansão dos espaços internos, a mente também se expande. (MELE, 2019, p.08)

Segundo Mele (2019) corpo e mente são contínuos, portanto abrir espaços nas articulações e mover expande e move a mente. Concordamos plenamente que corpo e mente são simultâneos e que a consciência corporal abre-se no corpo, dilatando a imersão em si mesmo - abre tempo e espaço na mente - para que a pessoa possa entrar em contato com o seu corpo e perceber a si própria: como respira, como bate seu coração, como são os seus ossos (comprimento, largura, altura, peso); articulações (forma e capacidade de movimento); músculos; pele; vísceras. Como pisa, como distribui o peso sobre os pés, como caminha, senta, deita, levanta. Como utiliza o olhar, a voz, a escuta, o olfato, o tato. Como se sente e entra em contato consigo e com os outros. E então, aplicar esta consciência corporal na ação de dançar. Pois, para Angel Vianna, todo o corpo dança.

A complexidade envolvida no sistema corpo pode ser vista por meio de níveis aparentemente separados. Essa é uma hipótese mais metodológica do que ontológica, típica do pensamento mais atomista, pois é bastante razoável que ocorram "movimentos" interníveis que variam desde o físico até o psicossocial. Do ponto de vista sistêmico, uma atuação em um dos níveis provocará efeitos e consequências nos demais, tal que elaborar a 
complexidade corporal física e biológica é elaborar vários desses níveis. Se levarmos em consideração que a complexidade humana é decorrente da evolução, temos a conclusão que a elaboração das dimensões complexas do ser humano pode gerar uma melhoria adaptativa da espécie (VIEIRA, 2009, p.34).

Esta consciência é desenvolvida na vivência prática do reconhecimento do corpo por meio do conhecimento orientado das estruturas anátomo-fisiológicas nas suas diferentes formas e funções, durante as aulas de MAV. Deste contato primário com o próprio corpo, advém a conscientização do movimento natural da vida, que permeia todos os tecidos do corpo humano. Da consciência corporal o corpo migra, gradativamente, para a consciência do movimento. De acordo com a professora Letícia Teixeira (2008) consciência do movimento é

a capacidade de interiorizar as pequenas percepções (...) troca energética e abertura de espaço interno (...) dirige-se para dentro do corpo, pelo lado obscuro do mundo ou para trás (...) corpo inteiro tomado pela consciência (...) É pela energia e pelo espaço tempo que se concebe a consciência do corpo (...) A consciência de si deve deixar de ver o corpo do exterior, e tornar-se uma consciência do corpo. (TEIXEIRA, 2008, p. 36)

Da consciência do movimento caminha-se para a criação da dança, como meio do corpo se permitir se estender pelo espaço coletivo através de jogos lúdicos e se deleitar no encontro com outros corpos no espaço.

A MAV educa considerando que primeiro é preciso saber que se tem um corpo e então considerar a biodiversidade dos corpos na sua experiência sensível e singular, tendo como parâmetro a consciência corporal, a consciência pelo movimento, o movimento e a dança como possibilidades de expressão intrínseca de cada pessoa.

A Consciência Corporal do movimento e da dança fazem parte de um processo educacional em que se desenvolve a criatividade, a comunicação e a alegria num percurso dinâmico, ao longo de toda a vida (SALDANHA, 2009, p.89).

Na Faculdade Angel Vianna podemos contemplar parâmetros para compreender as possibilidades da educação pelo movimento do corpo. Admitindo-se a consciência corporal e o movimento como partes indissociáveis do processo pedagógico de ensino-aprendizagem de "reconhecimentos". O estudante aprende a reconhecer primeiramente a existência da anátomo- 


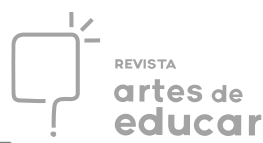

fisiologia do próprio corpo. Em seguida aprende diretamente na experiência cotidiana ao longo de todos os dias da sua formação, que este corpo é capaz de se movimentar em suas múltiplas possibilidades. Na sequência, começa a germinar a consciência do respeito por si mesmo. É desta consciência que nasce o respeito pelo corpo do outro, pelo espaço e pelo tempo.

Nesse contexto pedagógico de parâmetros bem definidos é que são desenvolvidas as habilidades do corpo do bailarino, do professor de dança, do educador, do terapeuta, do cientista do corpo em movimento. Reconhecer que se tem um corpo é pressuposto que proporciona um melhor uso do próprio corpo, ampliando gradativamente os níveis de consciência corporal no desejo de bem-estar e autocuidado. A partir deste lugar, as pessoas são capazes de estender essa consciência de si ao reconhecimento consciente do espaço, do tempo e do outro, possibilitando relações humanas de respeito e acolhimento.

\section{AnatomoPoesia}

As estrelas sempre foram caras ao coração das crianças e dos poetas, mas eles não sabiam muito bem por quê. A astrofísica dá corpo a este amor explicando que nossos átomos foram carregados pelo ventre das estrelas. $\mathrm{O}$ elo entre as estrelas e os homens, e de maneira mais geral entre todas as formas existentes no céu, é genético, material e histórico. O céu é feito de tantas histórias quanto de átomos. Toda luz torna-se palavra. (MICHEL CASSÉ apud MORIN, 2002, p. 36).

A semente da AnatomoPoesia vem sendo cuidada ao longo de 17 anos dentro do contexto acima narrado na Escola e Faculdade Angel Vianna (EFAV/RJ). A fecundação aconteceu ao longo de onze anos de estudos na escola técnica, na faculdade e na pós-graduação. Os primeiros ramos surgiram há seis anos, como professora de Danças Circulares Meditativas e de Anatomia Experimentada, no curso livre da escola. O broto despontou nos últimos dois anos, atuando como professora de Anatomia, Cinesiologia e Fisiologia, na graduação em licenciatura e bacharelado em dança. Neste momento, sigo em desenvolvimento, honrando os parâmetros aprendidos com a Mestre Angel Vianna e registrados em Saldanha (2009, p.89):

\section{- Primeiro é preciso saber que se tem um corpo.}

- Eu gosto é de gente.

- Gente é como nuvem, sempre se transforma.

- O que mais me comove na vida é um corpo abandonado, e como o corpo não mente... Cada vez mais percebo que escolhi o caminho certo!

Revista Interinstitucional Artes de Educar. Rio de Janeiro, V. 5, N.3- pág. 695-725 set-dez de 2019: “Educação: Corpo em movimento." - DOI: 10.12957/riae.2019.46727 


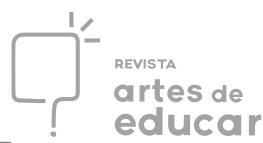

Em outras palavras, estas frases de Angel são a bússola a guiar a proposta pedagógica de integração dos saberes, cujo roteiro passo a apresentar:

A palavra AnatomoPoesia é a aglutinação das palavras anatomia e poesia. Anatomia deriva do grego Anatome. Ana significa em parte. Tome significa cortar. Poesia deriva do grego Poíesis que significa criar ou fazer. A aglutinação das duas palavras resultou no neologismo AnatomoPoesia - que para mim significa a ciência artística de integrar as partes na ação de criar/fazer, aqui e agora - por meio da consciência corporal - movimentos de composição no próprio corpo.

A AnatomoPoesia tem por objetivo geral integrar os saberes entre ciência, arte, natureza e consciência corporal. Os objetivos específicos são:

- Lecionar o conteúdo programático da disciplina Anatomia Aplicada à Dança com todo o aporte dos materiais didáticos clássicos como aulas teóricas, apostilas, power-point, animações, softwares, peças anatômicas, acrescido de experiências somestésicas, sensitivas, sensíveis, moventes, artísticas, desenvolvidas na prática vivencial em Plataformas Pedagógicas Sensitivas.

- Criar Plataformas Pedagógicas Sensitivas com materiais que dialoguem com as artes plásticas, a poesia, a contação de histórias, o teatro, a dança.

- Ambientar o espaço da sala de aula com as Plataformas Pedagógicas Sensitivas, proporcionando ao estudante o encontro com as suas inteligências múltiplas.

\title{
A Natureza
}

\begin{abstract}
Nossa proposta é que os seres vivos se caracterizam por, literalmente produzirem-se continuamente a si mesmos - o que indicamos ao chamarmos a organização que os define de organização autopoiética (...) O ser e o fazer de uma unidade auotpoiética são inseparáveis, e esse constitui seu modo específico de organização. (MATURANA e VARELA, 2001, p.84, 87, 89)
\end{abstract}

O corpo-natureza é simultaneamente continente e conteúdo. Isso quer dizer que o ser e o fazer são indissociáveis no corpo biológico. É essa capacidade da autoprodução de si, advinda do corpo biológico, que Maturana e Varela (2001) definem como autopoiese, na sua obra $A$ árvore do conhecimento. A autopoiese é a arte da reinvenção de si mesmo e do mundo, no tempo de duração da vida. Maturana e Varela (2001) compreendem o corpo humano integrado à natureza em si mesmo. Corpo formado pela menor unidade da vida organizada - a célula 
eucarionte animal - que constitui um sistema auto-organizado, que se autoproduz constantemente para poder existir.

Para esses autores, toda a sociedade/cultura/política, é produzida pelos corpos, que por sua vez são formados por trilhões de células, das quais são completamente dependentes, mesmo que passem a vida inteira sem se dar conta disso. São ideias que vão ao encontro de Angel Vianna que em comunicação oral diz: Primeiro é preciso saber que se tem um corpo. Ou seja, Angel reconhece o corpo como nossa primeira morada que requer consideração e conhecimento de si mesmo. E a educação pelo movimento pode ser um meio para ampliar e sustentar a vida na sua natureza criadora, conforme exposto acima.

\section{A Ciência}

Outro marco teórico vital para essa pesquisa é a obra do professor Roberto Lent (2010) Cem bilhões de neurônios, com base na qual apresento alguns conceitos sobre a estrutura e função do sistema nervoso: corpo somestésico, sentir/perceber, mover.

A apresentação desses conceitos tem a finalidade de elucidar a importância do conhecimento neuro-funcional acerca do fato de que todo o corpo humano é composto pelo sistema nervoso sensório-motor e não motor-sensório. Então pode-se afirmar: todo o corpo humano sente, logo, move.

As aulas de AnatomoPoesia são planejadas e as Plataformas Pedagógicas Sensitivas são criadas, em acordo com esses conhecimentos. Busca-se, a cada tema, advindo do conteúdo programático, integrar a teoria e a prática, sempre por meio de materiais aptos à criação das Plataformas Pedagógicas Sensitivas.

\section{Corpo Somestésico}

Durante a maior parte da nossa existência não nos damos conta do nosso corpo. Muita coisa acontece com ele minuto a minuto, mas só as mais significativas são registradas pela consciência, porque geralmente a nossa atenção está voltada para outros aspectos do ambiente, e o nosso corpo passa desapercebido. No entanto, embora a consciência não se dê conta de tudo, o sistema nervoso recebe e processa continuamente todas as informações sobre a posição e o movimento das partes do corpo e do corpo como um todo, sobre o estado de nossas vísceras, sobre a textura, a forma e a temperatura dos objetos que tocamos e sobre a integridade de nossos tecidos. Essas informações são selecionadas, filtradas e encaminhadas a diferentes regiões neurais, que as vão utilizar de diversas maneiras. A parte que atingirá a consciência servirá para orientar o comportamento e o raciocínio, podendo ser armazenada na memória para utilização posterior. A parte inconsciente servirá 
para coordenar os nossos movimentos de modo a manter a postura e o equilíbrio postural, e para ajustar o funcionamento dos órgãos e das vísceras de acordo com as necessidades fisiológicas (LENT, 2010, p. 211).

O sistema nervoso central é bem guardado no interior da caixa craniana e da coluna vertebral. Ao mesmo tempo é um continuum que abre-se à flor da pele, dos olhos, dos ouvidos, narinas, boca e esfíncteres. Todos os sentidos são requisitados e vivenciados durante a vida cotidiana: olfato, visão, audição, paladar. Porém, aqui proponho uma reflexão sobre o nosso Corpo Somestésico.

Segundo Teixeira (2008), que cita Angel Vianna, a pele é o "glacê" que cobre todo o corpo. É o nosso envelope, um órgão que reveste o corpo sem o qual não sobreviveríamos, pois sua função é de proteção. A pele é o maior órgão do nosso corpo e nos coloca em contato com o mundo, num dentro e fora simultâneos. É o tecido dotado, na sua estrutura histológica, dos receptores que detectam os estímulos do ambiente bioelétrico e que tocam o corpo. A pele é o órgão do sentido somestésico, sentido esse que se abre para o mundo e ao mesmo tempo se invagina na fáscia, nos músculos, nas articulações, nos ossos, nos órgãos.

De acordo com Lent (2010), a palavra Somestesia deriva do latim: Soma quer dizer corpo; aesthesia, sensibilidade. O sistema somestésico é a capacidade que as pessoas e os animais possuem de receber amplo conjunto de informações de diferentes partes do seu corpo. É uma modalidade sensorial, formada por muitas submodalidades, dispostas em teias sequenciais de neurônios, fibras nervosas e sinapses, que traduzem, codificam e modificam as informações provenientes diretamente da sensibilidade corporal. Nem todas essas informações se tornam conscientes, gerando a percepção. Algumas são inconscientes e utilizadas para a coordenação da motricidade e do funcionamento dos órgãos internos.

A complexa via nervosa aferente inscreve as informações captadas pela sensibilidade corporal no lobo parietal. Cria com as informações sensíveis, o mapa que representa no telencéfalo, no lobo parietal, as diversas partes sensíveis do corpo inteiro. Cito algumas das submodalidades de que nos fala a Somestesia, que, como visto, é o sentido da sensibilidade corporal global:

- Tato é a percepção das características dos objetos que tocam a pele. O tato pode ser fino, epicrítico. E grosso, protopático.

- Propriocepção é a capacidade de discernir a posição estática e dinâmica do corpo e suas partes. A propriocepção pode ser consciente e inconsciente. 
- Termossensibilidade é a capacidade de se perceber a temperatura do ar e dos objetos.

- Dor, é a capacidade de identificar estímulos muito fortes potenciais ou reais, causados por lesões nos tecidos. A dor pode ser aguda e crônica.

- Palestesia é a capacidade de sentir as vibrações.

- Topoestesia é a capacidade de discriminação de diferentes pontos que tocam a superfície da pele.

- Grafestesia é a capacidade de decodificação de símbolos escritos na pele.

- Esterognosia é a capacidade de reconhecer objetos com os olhos fechados.

\section{Sentir e Perceber}

Sensação é a capacidade que os animais apresentam de codificar certos aspectos da energia física e química que os circunda, representando-os como impulsos nervosos capazes de ser "compreendidos" pelos neurônios. A sensação permite a existência dos sentidos, ou seja, as diferentes modalidades sensoriais que advêm da tradução pelo sistema nervoso das diferentes formas de energia existentes no ambiente. Sistemas sensoriais, então representam os conjuntos de regiões, do sistema nervoso, conectadas entre si, cuja função é possibilitar as sensações. Percepção é um tanto diferente. Trata-se da capacidade que alguns animais apresentam - nem todos - de vincular os sentidos a outros aspectos da existência, como o comportamento, no caso dos animais em geral, e o pensamento no caso dos seres humanos (LENT, 2010, p.169).

Os sentidos são as estruturas receptoras que nos permitem detectar os estímulos. A percepção identifica o estímulo e nos leva a apreciá-lo ou não. Às vezes leva-nos a associá-lo a memórias de experiências vivenciadas em algum lugar do passado, ou seja, nos leva a lembrar.

A sensação tem como consequência a percepção que, por sua vez, não se encontra completamente disponível para a nossa consciência, pois passa pelo filtro da atenção, emoção e sono, dentre outros. A percepção é mais seletiva que os sentidos. O sistema nervoso tem mecanismos que bloqueiam informações sensoriais consideradas irrelevantes, concentrando-se num pequeno número de informações, consideradas mais importantes para a sobrevivência. A atenção concentrada é direcionada para "o que importa".

A percepção apresenta um nível de complexidade superior à sensação, ultrapassando os limites estruturais dos sistemas sensoriais e envolvendo outras partes do sistema nervoso de funções não-sensoriais. A espécie humana atingiu altos níveis de percepção, pois é capaz de se Revista Interinstitucional Artes de Educar. Rio de Janeiro, V. 5, N.3- pág. 695-725 set-dez de 2019: “Educação: Corpo em movimento." - DOI: 10.12957/riae.2019.46727 
indagar sobre a origem do passado, presente e futuro das coisas, incluindo-se nessa indagação. É capaz de elaborar pensamento, emoção e atitudes autoinvestigativas, com relação a si, por meio do autoconhecimento e com relação ao todo, em decorrência do reconhecimento percebido do espaço circundante. O ser humano é capaz de imaginar coisas e confeccioná-las. O corpo do ser humano é capaz de planejar e construir novos objetos passíveis de ampliar ainda mais sua capacidade perceptual.

\title{
Mover
}

\begin{abstract}
No homem a motricidade assumiu grande complexidade, uma vez que as mãos se tornaram menos dependentes das necessidades posturais, podendo assim ser utilizadas para diversos fins, em especial para a confecção de utensílios e instrumentos. Além disso, associaram-se funcionalmente ao rosto para operar um sofisticado sistema de comunicação e expressão de ideias e sentimentos. Mas os movimentos não dependem apenas dos músculos, como se poderia pensar. São o resultado de complexos processos de programação, comando e controle que envolvem diversas regiões cerebrais e terminam na contração das fibras musculares. Esse conjunto neuromuscular é conhecido como sistema motor (LENT, 2010, p.343).
\end{abstract}

No ser humano, o sistema nervoso é sensitivo e motor - mas primeiramente sensitivo. Para haver aprendizagem motora é necessário sentir. Se o corpo não sente, não responde. Por isso, quanto maior o déficit sensitivo, maior o déficit motor. Quanto mais sensorial o corpo, mais motor. O corpo é controlado pelo alto comando sensório-motor. Mover é parte do complexo sistema neuro-sensório-motor.

O corpo humano é dotado de dois grandes centros motores: o sistema nervoso central, protegido pelo esqueleto axial, e o sistema nervoso periférico que se expande em direção ao esqueleto apendicular. Os centros organizadores do córtex e das regiões subcorticais comandam as ações do corpo pelas vias descendentes ou eferentes do movimento, por meio do potencial de ação e das sinapses entre os neurônios.

O conhecimento científico ensina que o movimento é composto por sequências complexas que associam, no sistema neuromuscular, coordenação motora e modulação da força, da velocidade, da amplitude e da direção de cada movimento com precisão. Simultaneamente, o corpo realiza movimentos voluntários, ações involuntárias, movimentos de equilíbrio corporal, atos de locomoção, movimentos oculares de estabilização da imagem, com 
olhares de busca de alvos distantes. Os movimentos cotidianos inscrevem no lobo frontal o mapa somatotópico motor.

Cada ser humano é dotado de um corpo singular, com o qual vive as suas experiências, formando o seu próprio dicionário dos movimentos usados no dia-a-dia, o engrama neuromotor. O engrama é formado durante as interações do corpo com as experiências no meio social (relações com a família, sociedade, cultura, necessidades, desejos). De acordo com Lent (2010) a motricidade é a expressão do comportamento e o mais nítido resultado da consciência humana. A consciência humana está, portanto, vinculada ao movimento do corpo.

\section{A Arte - Plataformas Pedagógicas Sensitivas}

O que importa é lançar as sementes no corpo de cada um, abrir espaço na mente e nos músculos. E esperar que as respostas cheguem. Ou não. Todo este trabalho tem qualquer coisa de paradoxal: fala de coisas que devem ser sentidas e não pensadas (VIANNA, 2005, p.89).

Ao reconhecer nos conceitos neuro-funcionais descritos acima a importância do corpo somestésico, dos sentidos, da percepção e do movimento, penso que os corpos dos discentes precisam primeiramente ser considerados na sua sensitividade durante os processos de ensinoaprendizagem, pois o corpo sente, logo move. O corpo humano é sensibilidade e movimento. Como diz a Mestre Angel Vianna em comunicação oral: o corpo humano é feito de ossos, músculos, articulações, pele e amor. Inspirada nesses pensamentos, criei para a pesquisa AnatomoPoesia, as Plataformas Pedagógicas Sensitivas.

Plataformas Pedagógicas Sensitivas são ambientes confeccionados para receber os estudantes e acolher os seus corpos sensíveis. Compreendo que é a conexão com a sensibilidade que possibilita a manifestação das inteligências múltiplas. São objetivos específicos das plataformas:

- Sensorializar o conteúdo teórico das narrativas científicas;

- Convidar o sujeito a reconhecer a teoria científica na prática artística de si mesmo;

- Refletir sobre Conhecer como Conhecemos.

As plataformas são confeccionadas com objetos cotidianos, como pequenos brinquedos, contas de miçangas, espelhos de diversos tamanhos, utensílios de cozinha, algodão cru, canetinhas, blocos mágicos, papéis e luzes. Assim surge o continente - plataforma pedagógica - que irá sensorializar o conteúdo programático científico, que por sua vez foi preparado com Revista Interinstitucional Artes de Educar. Rio de Janeiro, V. 5, N.3- pág. 695-725 set-dez de 2019: "Educação: Corpo em movimento." - DOI: 10.12957/riae.2019.46727 
toda ética, a partir da teoria científica e será experimentado artisticamente pelos estudantes e o professor, na ação de sentir, tocar, mover os objetos.

As propostas trazidas pelos objetos são pensadas pelo professor, a partir da compreensão do conceito de corpo somestésico e as múltiplas vias das inteligências,

É fácil conceber que a inteligência não é fruto do trabalho de um único órgão; ela é inerente à vida, seja cerebral ou não (...) não consigo imaginar nenhum tipo de inteligência que não tenha um tipo de memória própria, mesmo peculiar. De fato, memória é algo diferente da inteligência em si. Sem a primeira, não é possível aprender, e a aprendizagem é um dos requisitos da própria inteligência (...) em geral os organismos são capazes de aprender com a experiência (...) Tudo isso não poderia acontecer sem a capacidade de armazenar informações relevantes em algum lugar para superar obstáculos específicos. (MANCUSO, p. 18, 2019)

Mancuso (2019) amplia o horizonte das possibilidades de concepção de ensinoaprendizagem, ao observar que a memória e a inteligência, são inerentes à vida e servem à aprendizagem na superação de obstáculos. Como observa-se em Lent (2010) memória e inteligência são processos, organizados no corpo humano na forma de sistema nervoso sensório-motor, ou seja, a célula eucarionte animal funciona assim - tem o cérebro como sede - mas, não se reduz a isso. Pois, o corpo somestésico nos mostra que inteligência, memória e aprendizagem também podem se dar por outras vias, como acontece no mundo das plantas estudadas por Mancuso (2019) em A Revolução das Plantas.

Nesta obra, aprende-se que os corpos derivados das células eucariontes vegetais - as plantas - também recebem, processam e transmitem informações, memória, inteligência e aprendizagem. O fato de não sabermos como o processo de inteligência acontece no reino vegetal, não que dizer que a informação, memória, aprendizagem, inteligência e organização, inexistam ali. Segundo o autor, é possível aprender com as experiências que viram memórias armazenadas, pois estas são informações que ao longo do tempo nos transformam, por meio da experiência do aprendizado, e nos possibilitam a superação dos obstáculos. E esse é o ponto que importa nos processos de ensino-aprendizagem. O ponto que importa é a validação das experiências que todo o corpo humano vive. Pois, é o estudo e reconhecimento das experiências do corpo humano, no mundo das relações entre os seres humanos consigo mesmo, com o outro, com o espaço e o tempo - que gradativamente desabrocham a flor da consciência dos movimentos. Trata-se de um processo de ensino-aprendizagem que faça sentido para a vida de todos os envolvidos. E esse processo começa pela educação pelo movimento, a Consciência Revista Interinstitucional Artes de Educar. Rio de Janeiro, V. 5, N.3- pág. 695-725 set-dez de 2019: "Educação: Corpo em movimento." - DOI: 10.12957/riae.2019.46727 


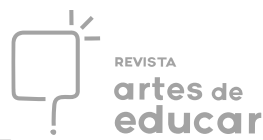

Corporal. Eis o maior legado da Bailarina e Pedagoga do Movimento, a brasileira, Angel Vianna (1928). É isso que ensina sua escola e faculdade. É isso que faz com que todos os estudantes da sua educação pelo movimento amem estudar na sua escola. E o amor é essencial na educação, na sociedade, na cultura, na vida.

Comparemos o pensamento de Mancuso (2019) ao de Howard Gardner (1994) que, em sua obra Estruturas da Mente (1994), apresentou uma Teoria das Inteligências Múltiplas, reforçando a perspectiva intercultural da cognição humana, capaz de dispor de múltiplas possibilidades criativas para a resolução de problemas. De acordo com Campbell (2000), Gardner mapeou oito inteligências: verbo-linguística, interpessoal, intrapessoal, naturalista, corporal-cinestésica, musical, lógico-matemática, espacial-visual. Mancuso (2019) e Gardner (1994) consideram que as experiências são informações que geram memórias. A memória leva os organismos vivos ao processo de aprendizagem, que no decorrer do tempo inventa soluções criativas para a resolução dos seus problemas.

Portanto, é relevante considerar o corpo somestésico, que de acordo com Lent (2010), é formado por múltiplos captores de mundo por meio de pequenos órgãos de sensibilidade dispostos da superfície da pele a profundidade das vísceras. E são estes órgãos somestésicos que constituem os nossos corpos de memórias, advindos das experiências e inscritos em todos os tecidos do nosso corpo humano; memórias armazenadas na sensibilidade, sentidos, percepção e movimentos do corpo inteiro.

Pensamos no corpo de memórias, como um mosaico, que pode se reinventar, se autoproduzir e reorganizar, capaz de configurar e reconfigurar o corpo. Volto a citar Lent (2010), em sua afirmação de que todo corpo sente e, daí se move. Isso quer dizer que, por meio da abertura das portas da sensibilidade, convida-se o sujeito a estar presente no exercício do movimento. Essa presença corporal é matéria de estudo da educação pelo movimento do corpo, é aí que aflora a consciência corporal - que, por sua vez, configura a prática conectiva do sujeito integral: corpo, emoção, mente, sociedade, cultura, política, natureza.

Sabe-se também que a atenção, quando aguçada por meio dos sentidos, gera movimentos - conscientes e inconscientes - conectando às áreas encefálicas envolvidas com o corpo inteiro, como processamento somestésico. Isso torna o sujeito ativo na experiência de si e do mundo, favorecendo-o com um conhecimento teórico-prático que lhe acrescenta as inteligências múltiplas, da qual a razão cognitiva é mais uma. Essa experiência pode ser somada à sensibilidade, empatia, cocriação, pertencimento e consciência de si mesmo. Assim se amplia o horizonte do contex to do protagonismo social e da autonomia de cada sujeito na coletividade. 


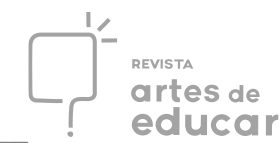

É importante observar que o tempo/espaço da experiência do discente em sala de aula precisa ser respeitado para que se crie um vínculo entre a aula proposta pelo professor e a própria vida do estudante. Volto a Maturana e Varela:

O amor ao próximo começa a aflorar então no entendimento dos processos que geram o fenômeno existencial da consciência de si, numa expansão dos impulsos naturais de altruísmo comunitário, precisamente como a condição necessária do social, e não como uma imposição de uma supranatureza diferente da nossa. (MATURANA e VARELA, 2001, p.50)

Por isso é tão importante para o século XXI conciliar a educação pelo conhecimento, pela consciência do corpo e a educação pelo movimento do corpo. É necessário irradiar o conhecimento científico da estrutura, função e movimento do corpo humano para o corpo vivo - por e com ele - apropriando-se do trabalho de conhecimento de si, também como possibilidade de atenção primária à saúde. A ênfase situa-se nas "possibilidades". Em tudo que um corpo é capaz de realizar "apesar de" e "contudo". Aqui levamos em consideração a anatomia, fisiologia, morfologia, singularidade de cada corpo - porém dentro do espaço aberto das possibilidades e da experimentação.

Nas Plataformas Pedagógicas Sensitivas as conexões do esquema neuro-sensório-motor assumem a possibilidade de ser ampliadas, gerando um espaço de reinvenção das linguagens gravadas, transpassadas e assimiladas no funcionamento psíquico-mecânico. Assim cria-se oportunidade de conexão do discente com as suas inteligências múltiplas. Para ilustrar um pouco do que escrevemos até aqui, nas próximas páginas apresento algumas fotografias das aulas temáticas no cenário das Plataformas Pedagógicas Sensitivas.

\section{Fotografias das Plataformas Pedagógicas Sensitivas}

Não decore passos, aprenda um caminho! (VIANNA, 2005) 


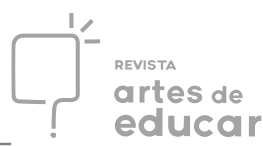

Plataforma Pedagógica Sensitiva da aula - A Célula - realizada em abril de 2017, na Faculdade Angel Vianna/RJ.

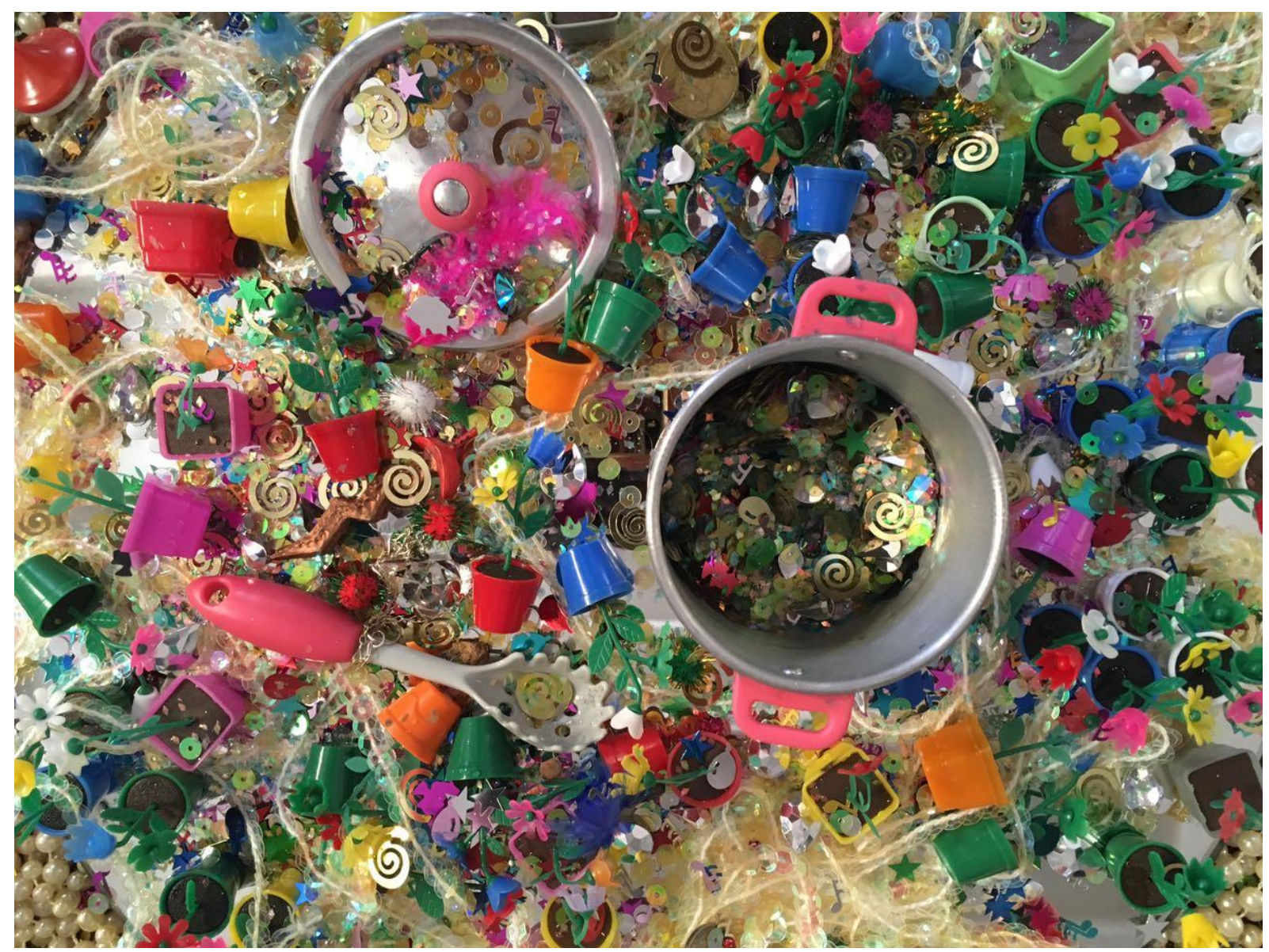

Foto: Vanessa Matos
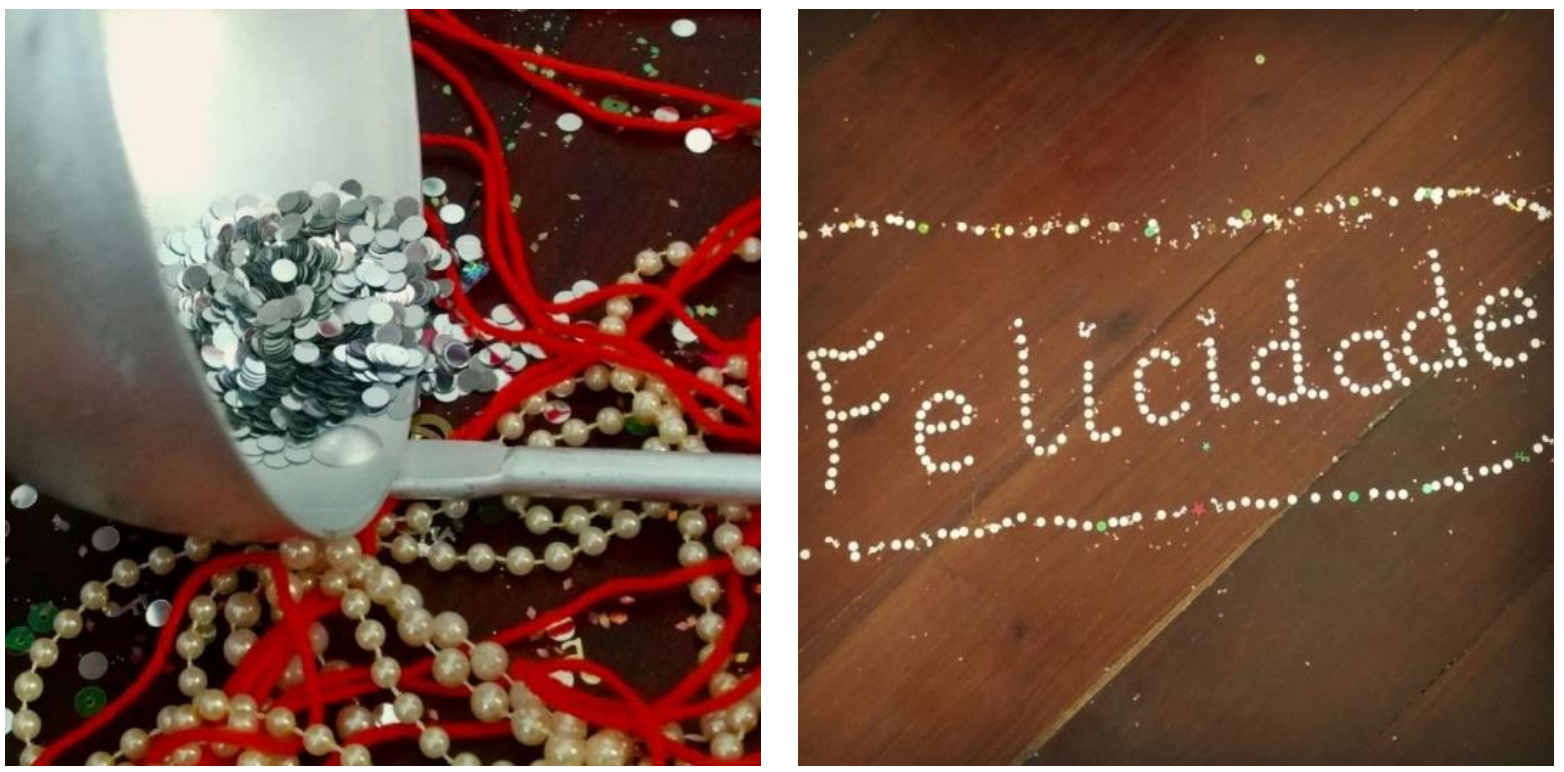

Foto: Vanessa Matos.

Revista Interinstitucional Artes de Educar. Rio de Janeiro, V. 5, N.3- pág. 695-725 set-dez de 2019: "Educação: Corpo em movimento." - DOI: 10.12957/riae.2019.46727 


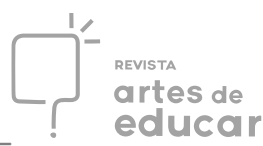

Plataformas Pedagógicas Sensitivas montadas na Imersão em AnatomoPoesia, realizada em julho de 2018, no Espaço de Residência Artística Vale Arvoredo/RS.

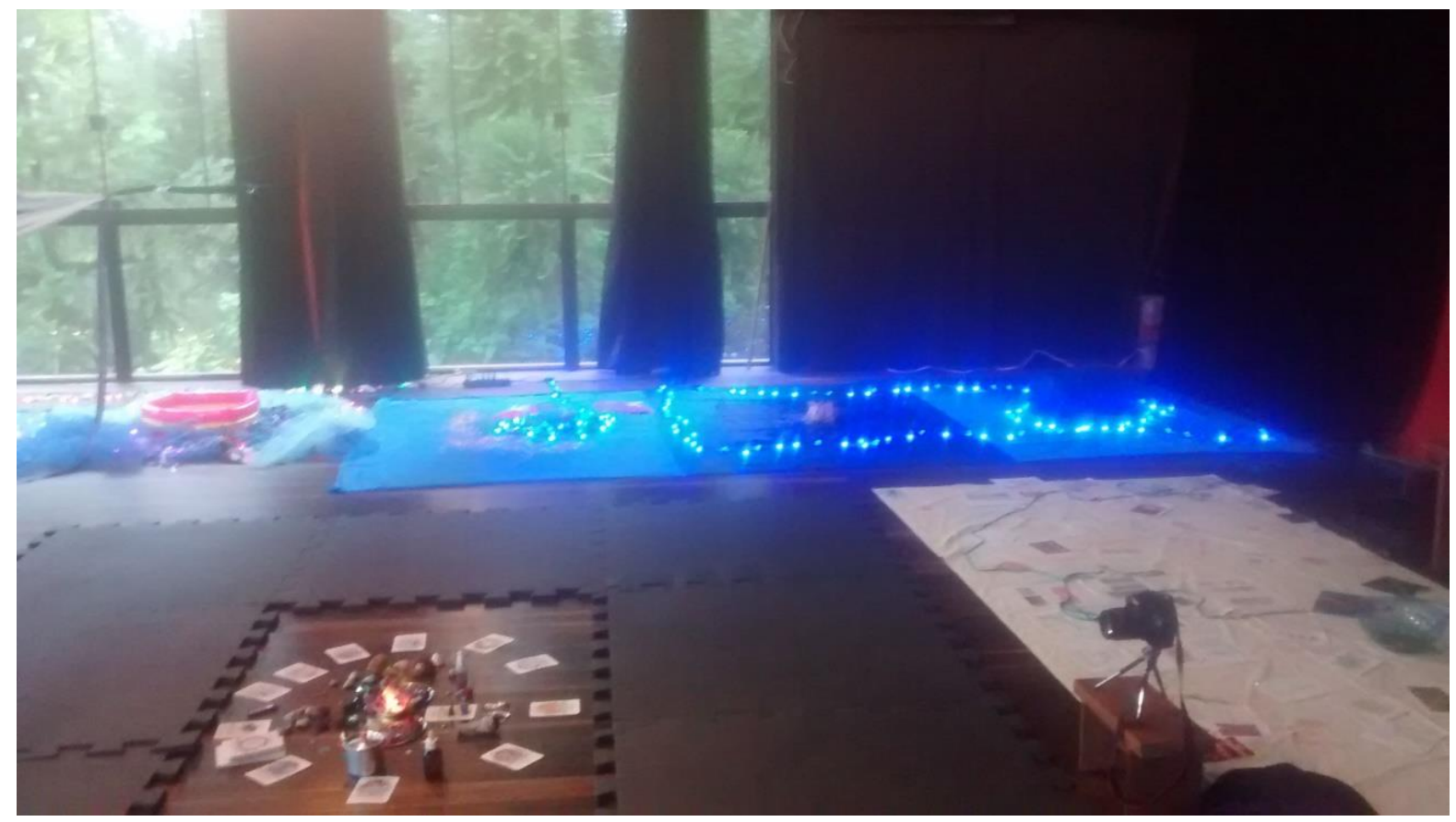

Foto: Carol Garcia.

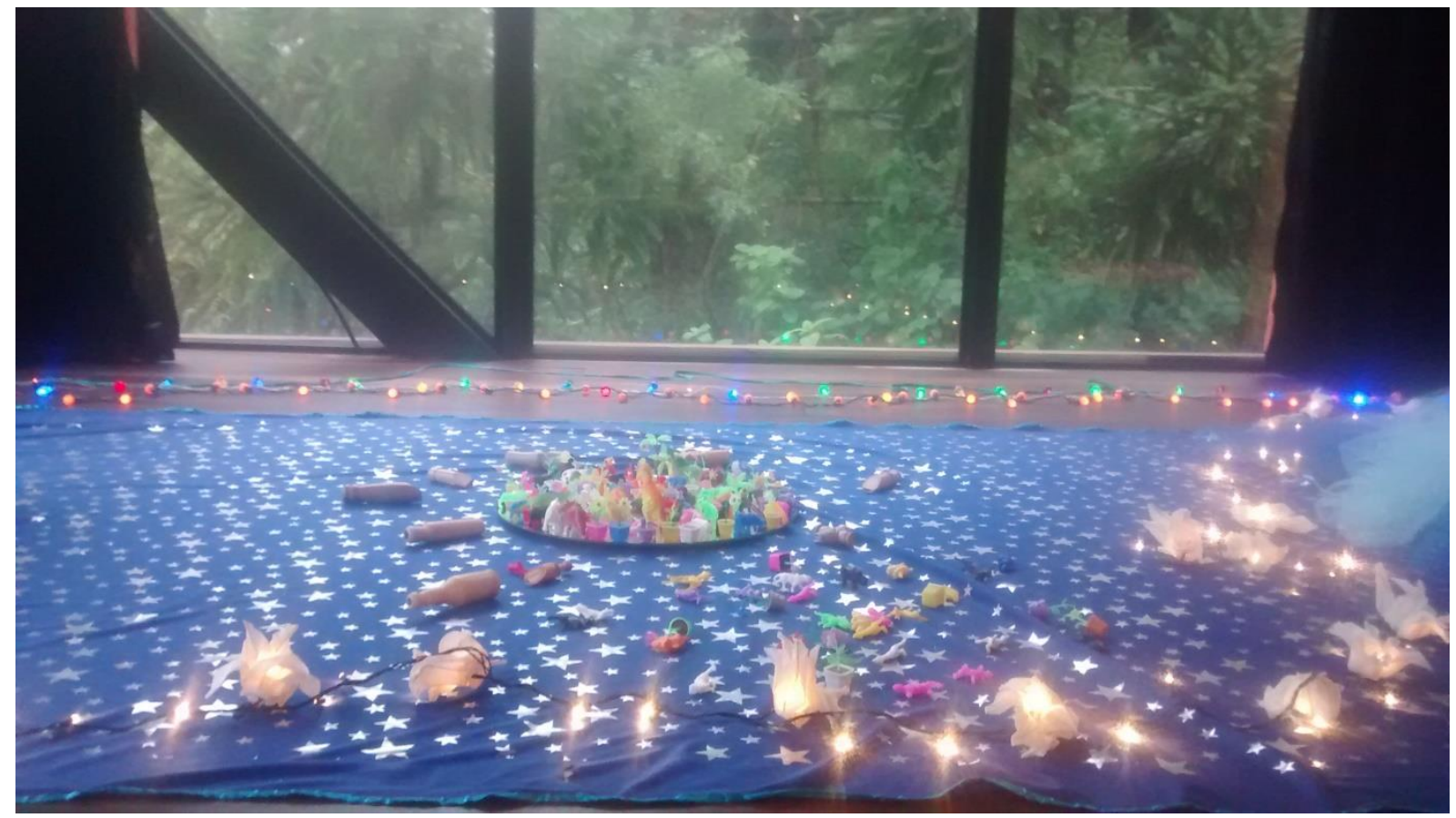

\section{Foto: Carol Garcia.}

Revista Interinstitucional Artes de Educar. Rio de Janeiro, V. 5, N.3-pág. 695-725 set-dez de 2019: "Educação: Corpo em movimento." - DOI: 10.12957/riae.2019.46727 


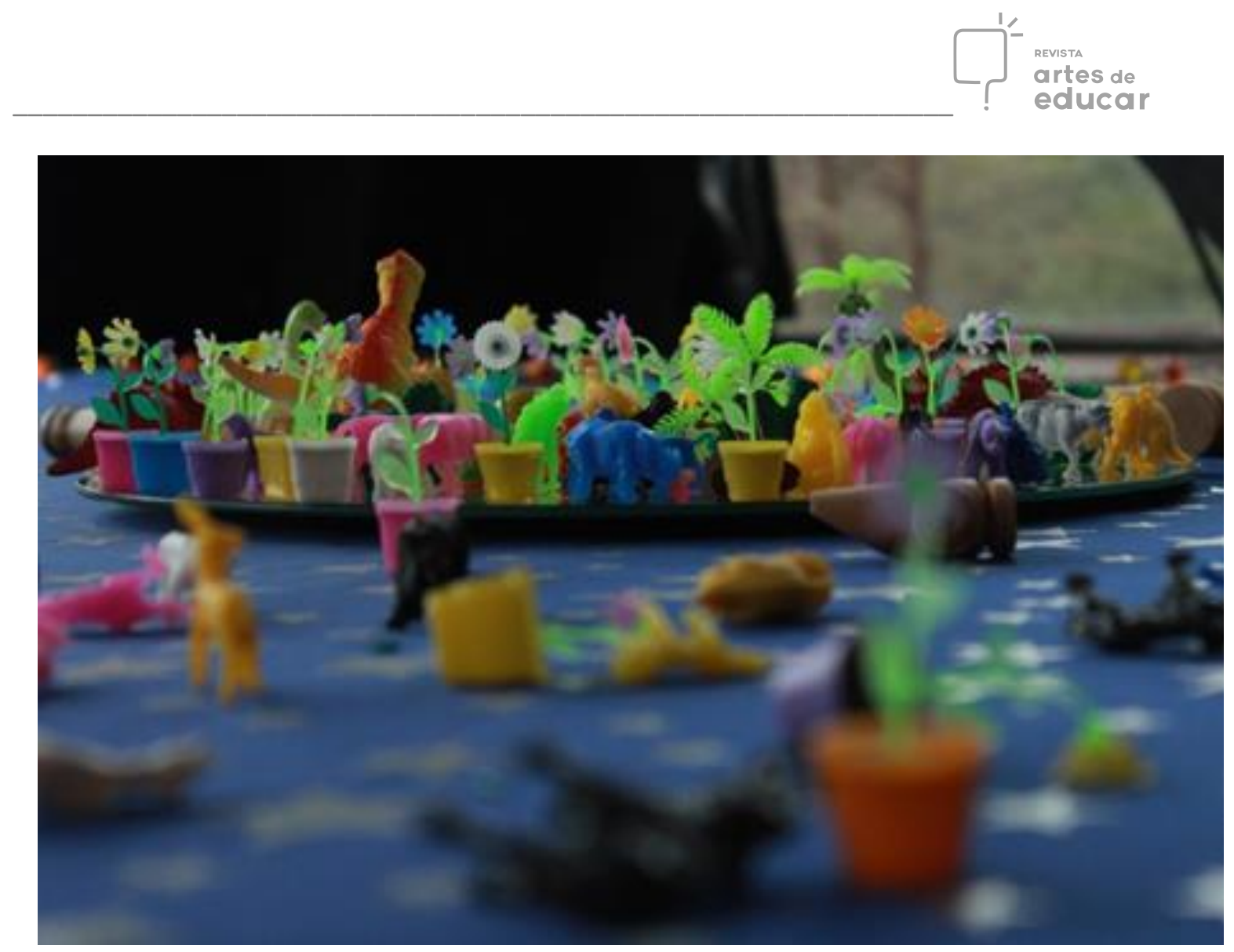

Foto: Isadora Farage.

Plataforma Pedagógica Sensitiva da aula - O Cerne: Esqueleto Axial - realizada em agosto de 2018, na Faculdade Angel Vianna/RJ.

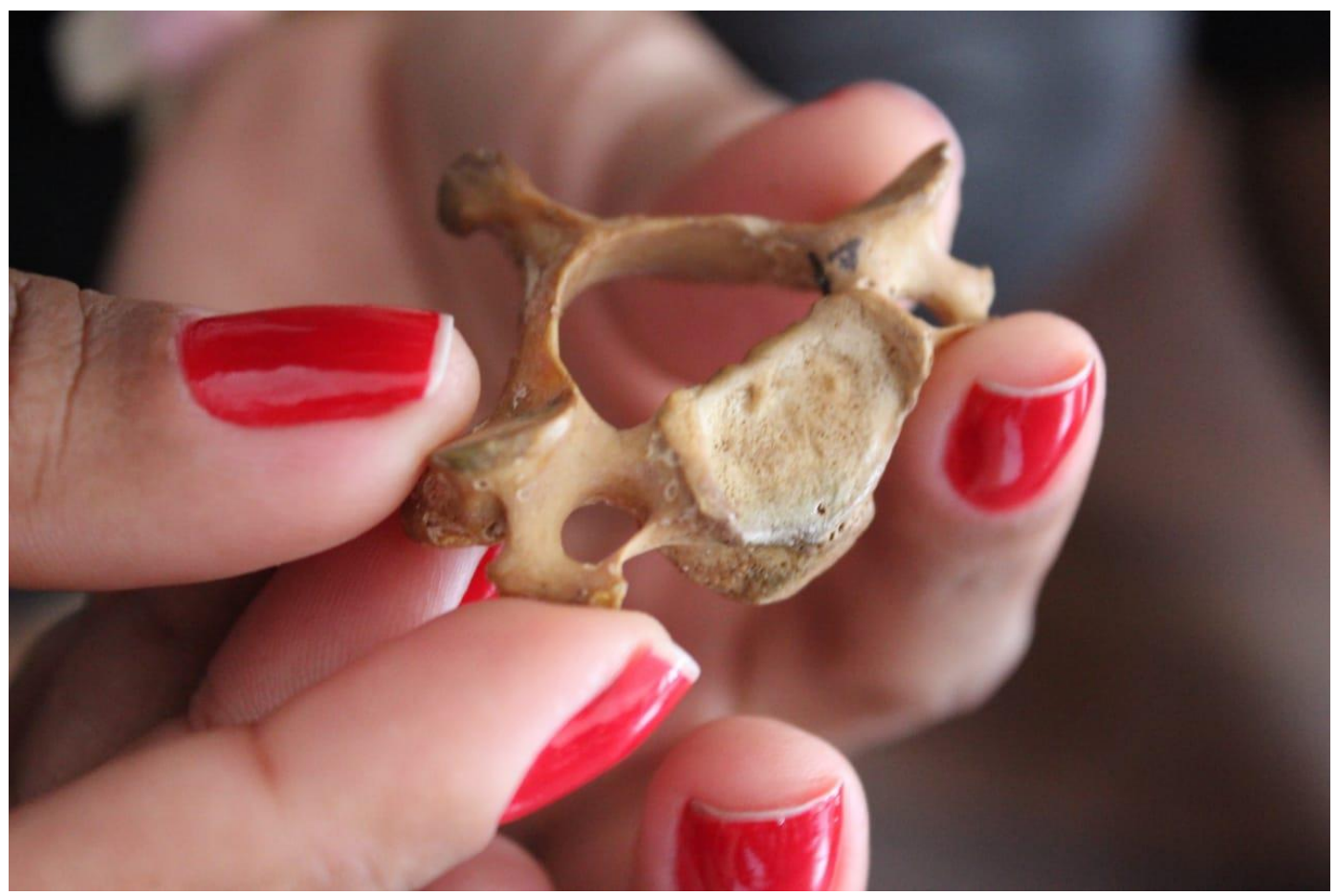

Foto: Eduardo Ramos.

Revista Interinstitucional Artes de Educar. Rio de Janeiro, V. 5, N.3- pág. 695-725 set-dez de 2019: "Educação: Corpo em movimento." - DOI: 10.12957/riae.2019.46727 


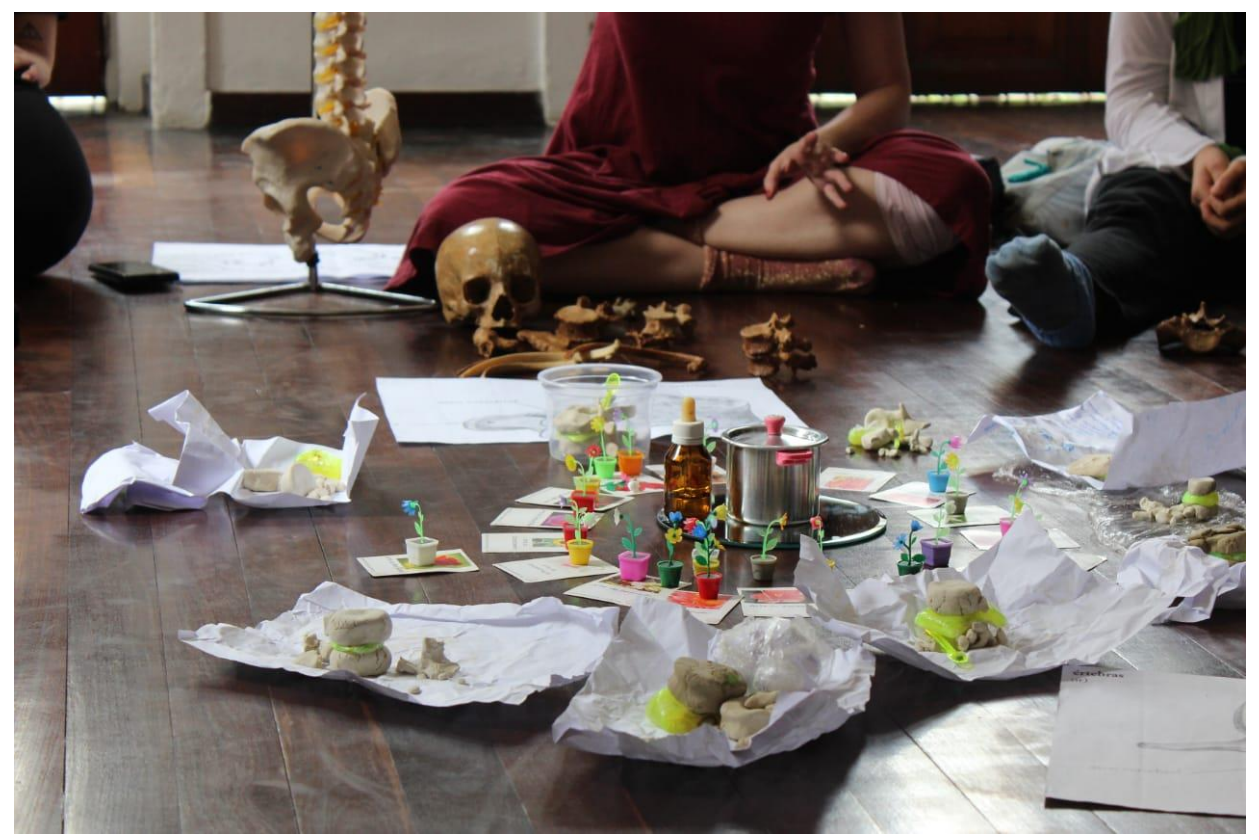

Foto: Eduardo Ramos.

Exposição de AnatomoPoesia na Mostra da Faculdade Angel Vianna. A exposição apresentou os estudos dirigidos, feitos pelos estudantes da turma 2018.2, da disciplina Anatomia aplicada à Dança, lecionada nos princípios da AnatomoPoesia. Dezembro de 2018 no Centro Coreográfico do Rio de Janeiro/RJ.

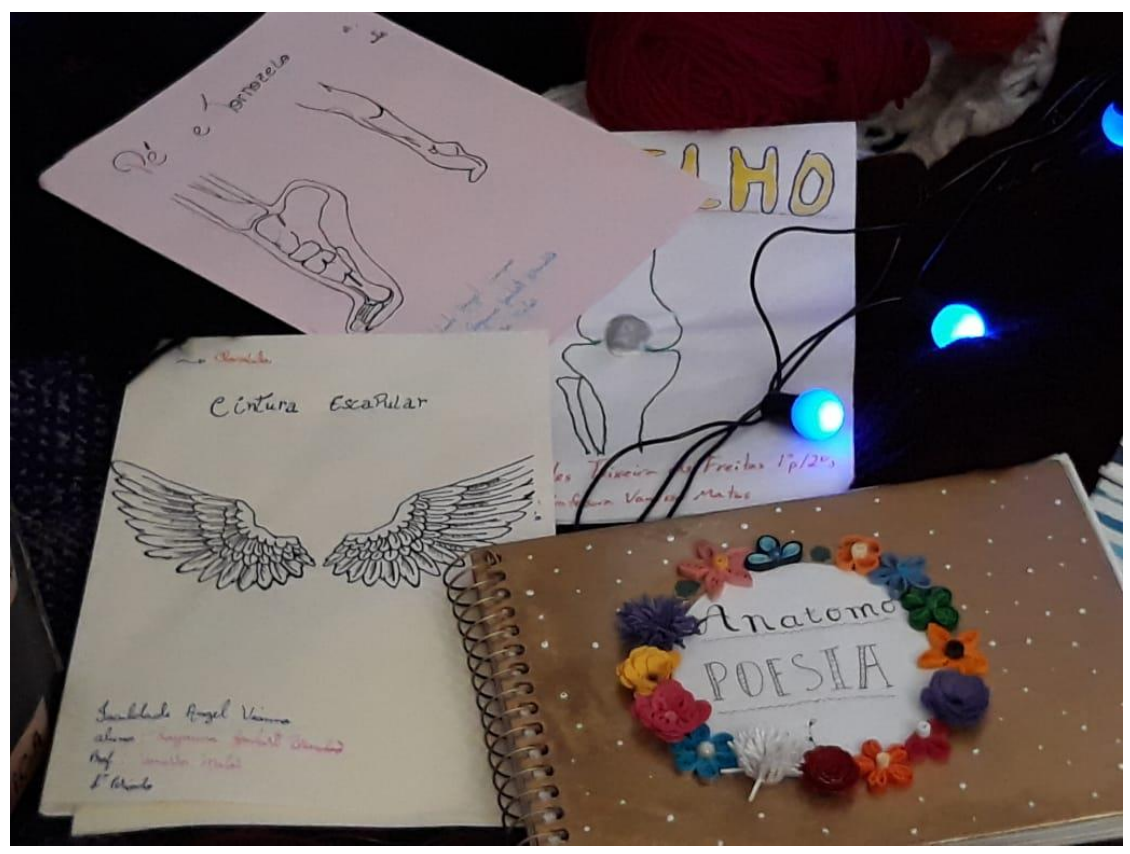

Foto: Flávia Massena.

Revista Interinstitucional Artes de Educar. Rio de Janeiro, V. 5, N.3-pág. 695-725 set-dez de 2019: "Educação: Corpo em movimento." - DOI: 10.12957/riae.2019.46727 


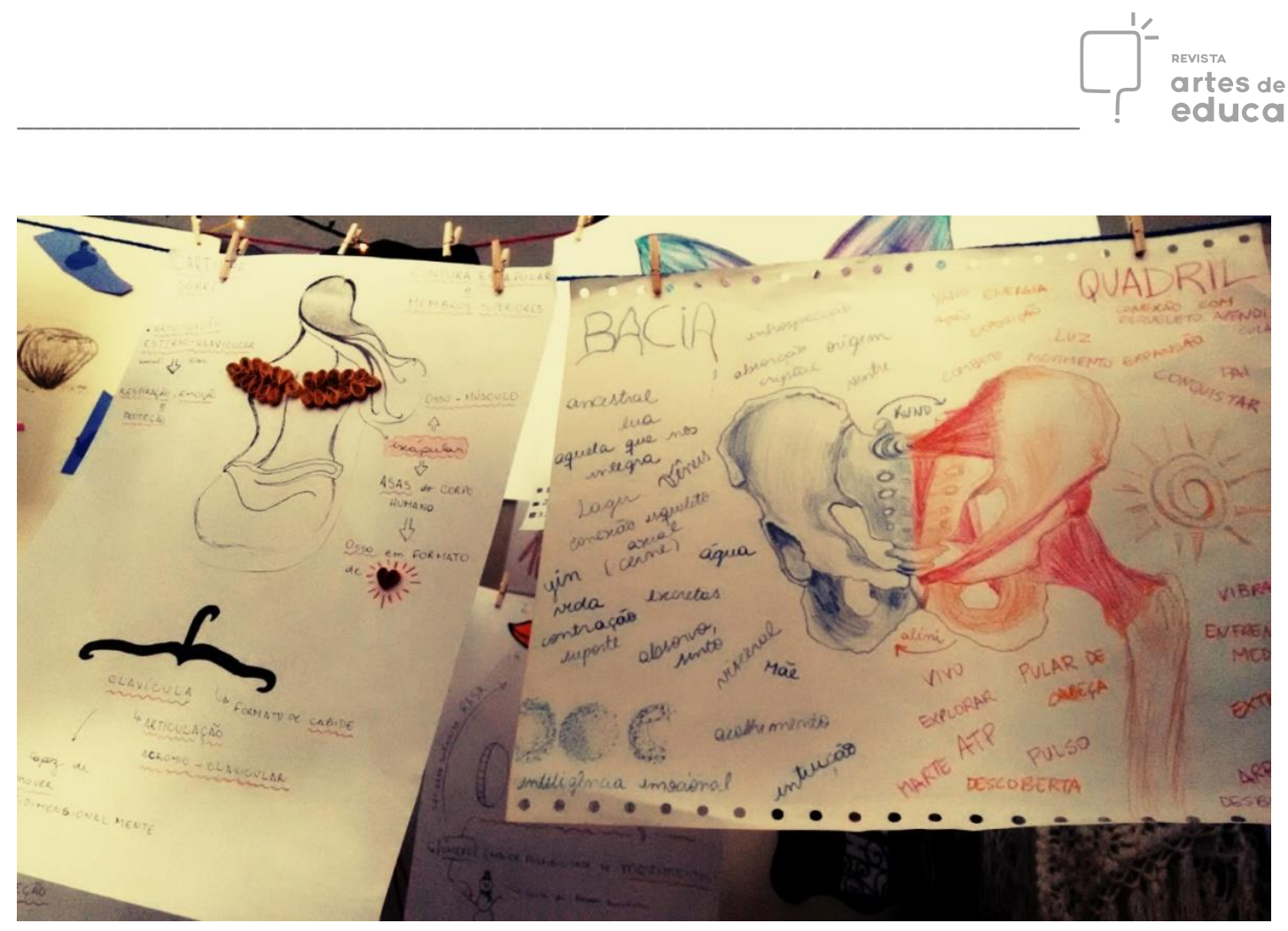

Foto: Flávia Massena.

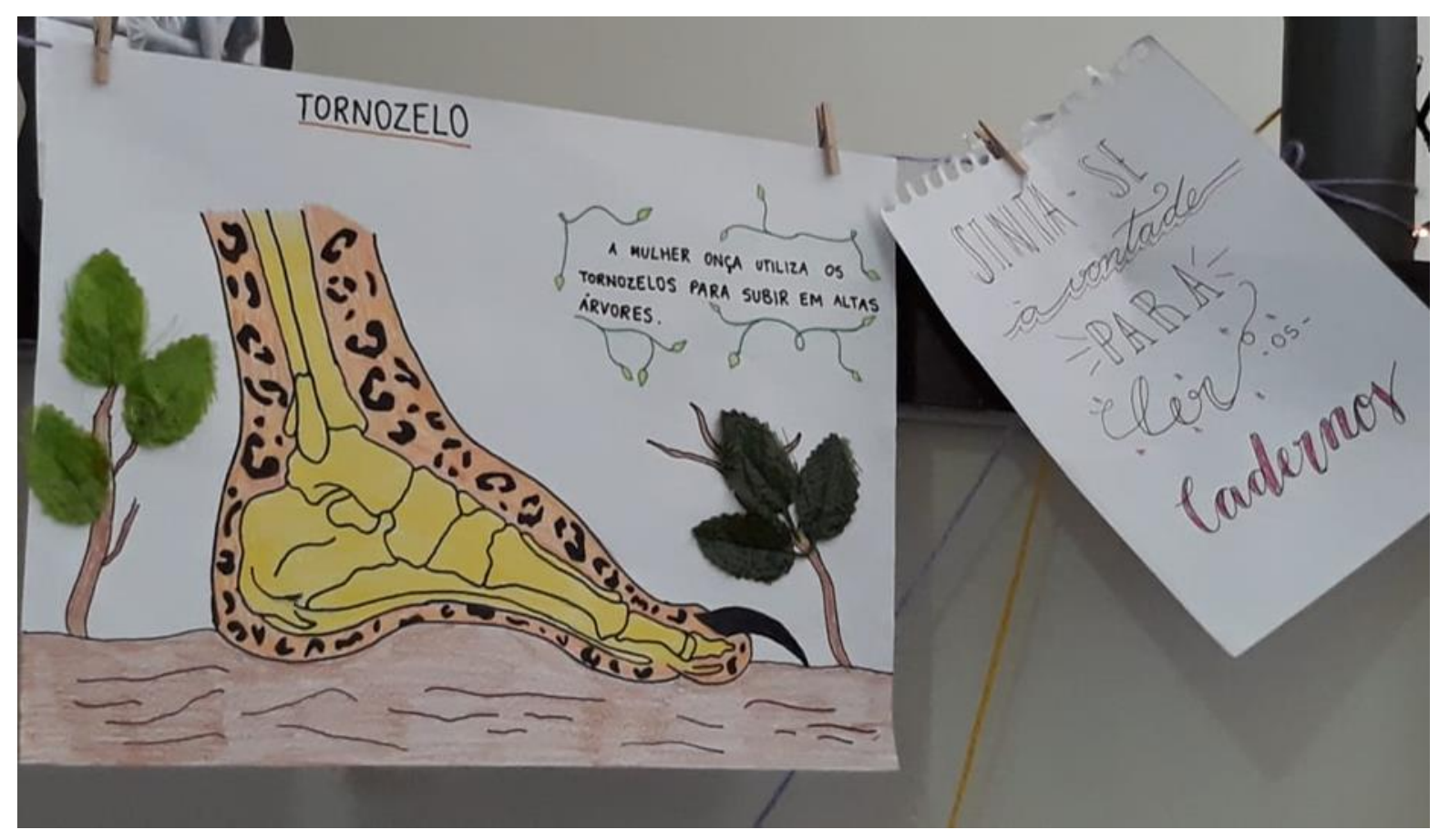

Foto: Flávia Massena.

Revista Interinstitucional Artes de Educar. Rio de Janeiro, V. 5, N.3- pág. 695-725 set-dez de 2019: "Educação: Corpo em movimento." - DOI: 10.12957/riae.2019.46727 


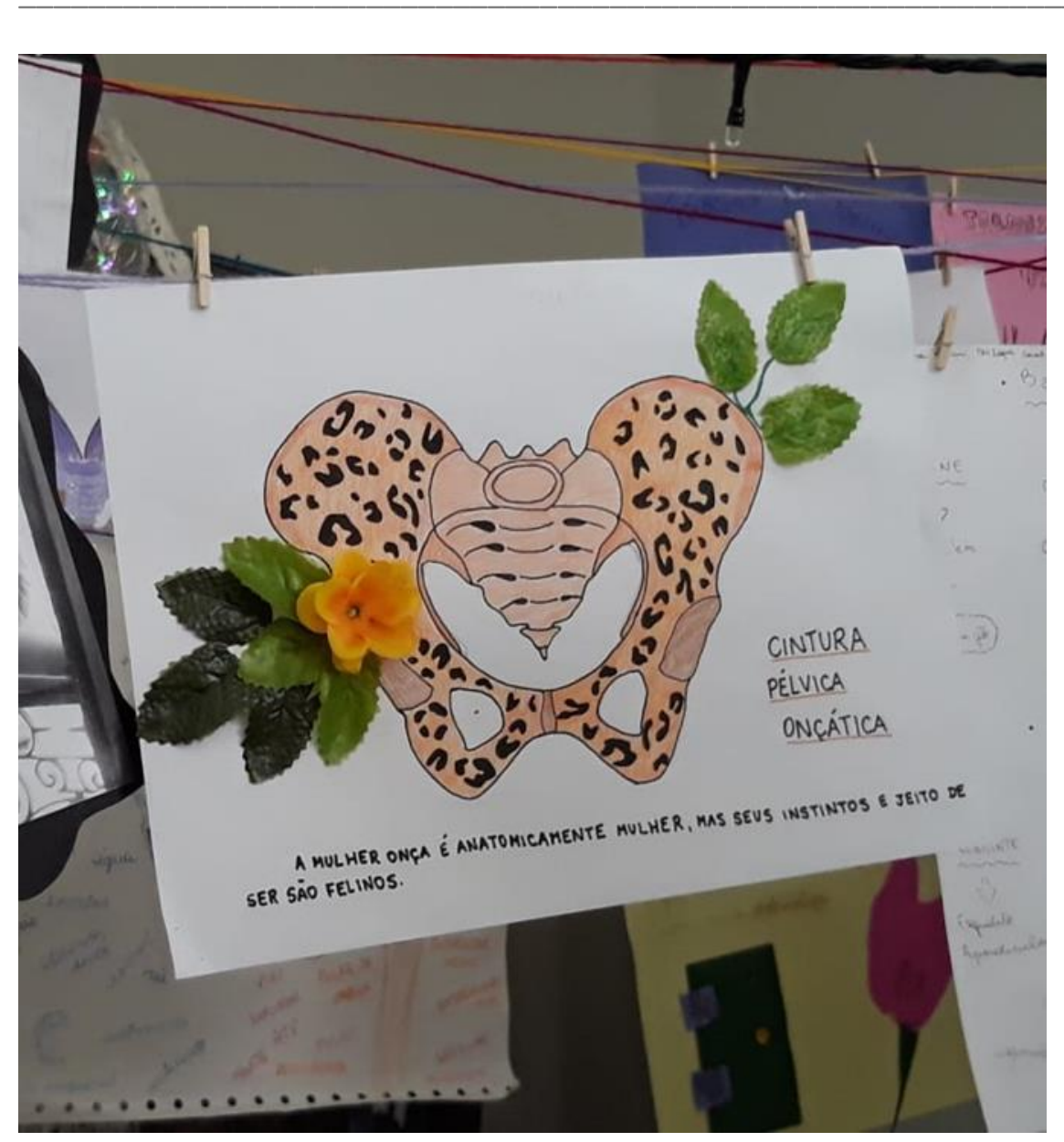

Foto: Flávia Massena.

Plataforma Pedagógica Sensitiva da aula - Tecido Conjuntivo - realizada em agosto de 2019 na Faculdade Angel Vianna/RJ.

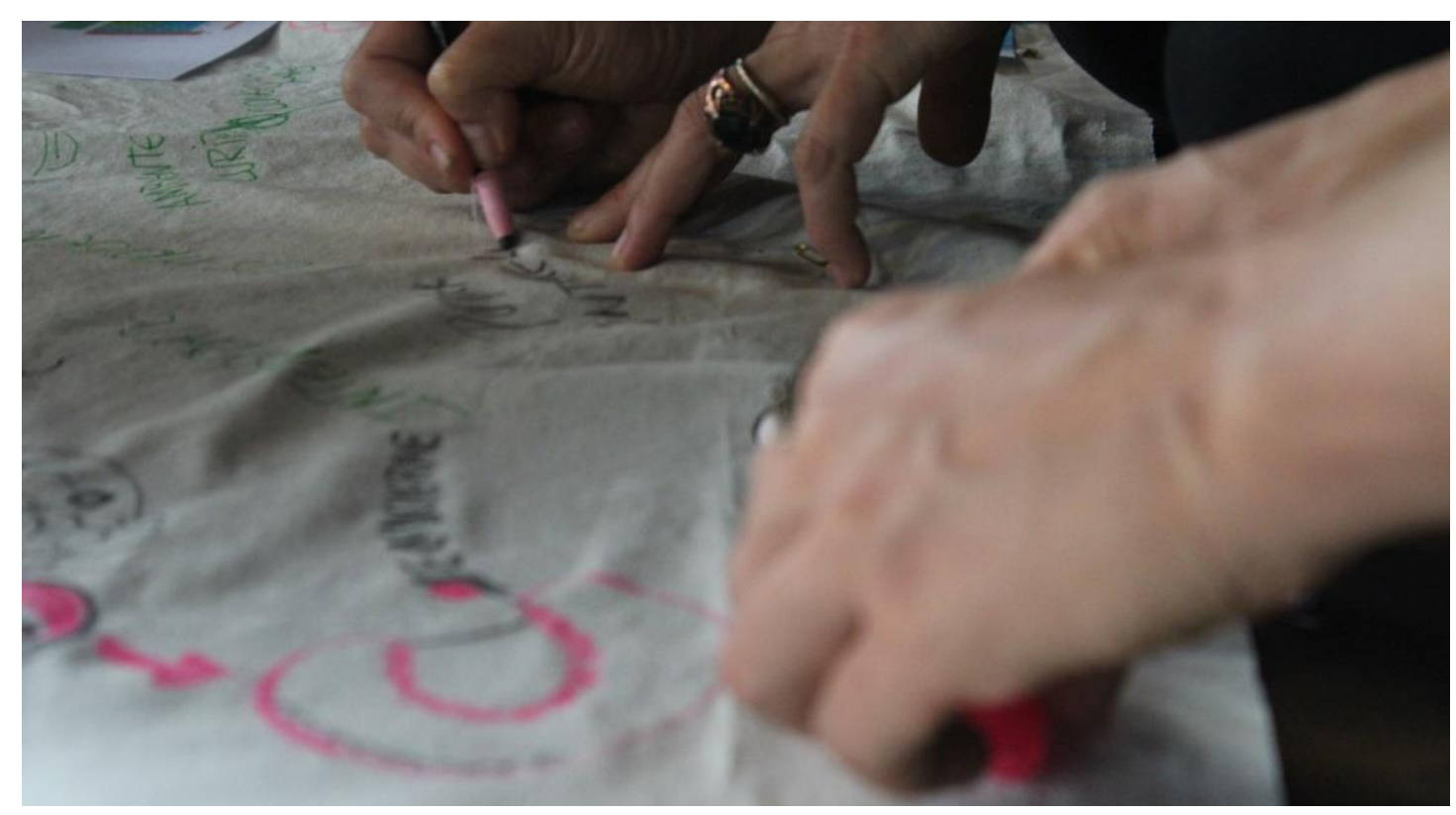

Foto: Isadora Farage.

Revista Interinstitucional Artes de Educar. Rio de Janeiro, V. 5, N.3- pág. 695-725 set-dez de 2019: "Educação: Corpo em movimento." - DOI: 10.12957/riae.2019.46727 


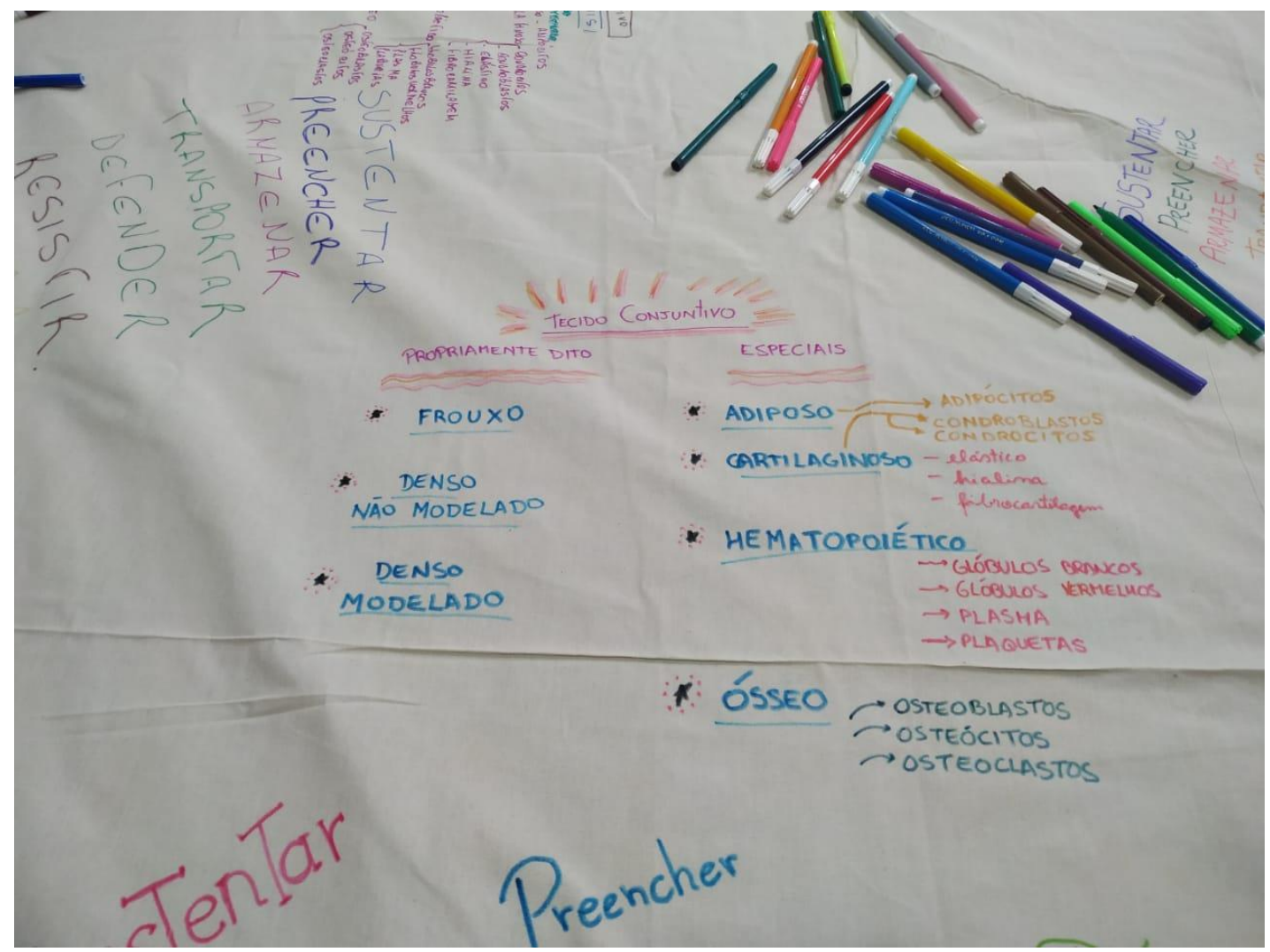

Foto: Isabelle Gusmán Von Leiss.

Plataforma Pedagógica Sensitiva da aula - Sinto logo Movo - realizada em setembro de 2019 na Unirio/RJ.

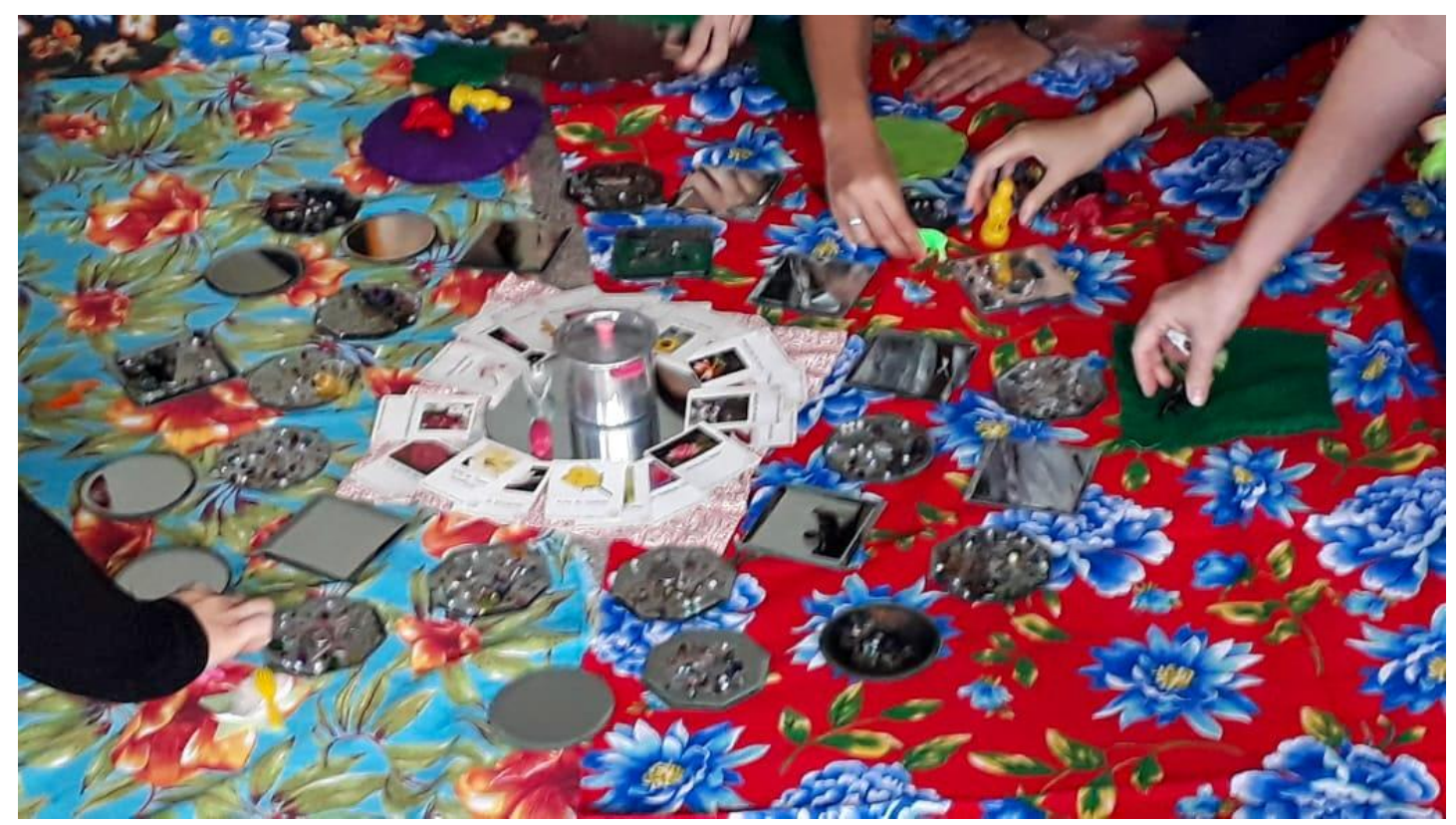

Foto: Adrianne Ogêda.

Revista Interinstitucional Artes de Educar. Rio de Janeiro, V. 5, N.3- pág. 695-725 set-dez de 2019: "Educação: Corpo em movimento." - DOI: 10.12957/riae.2019.46727 

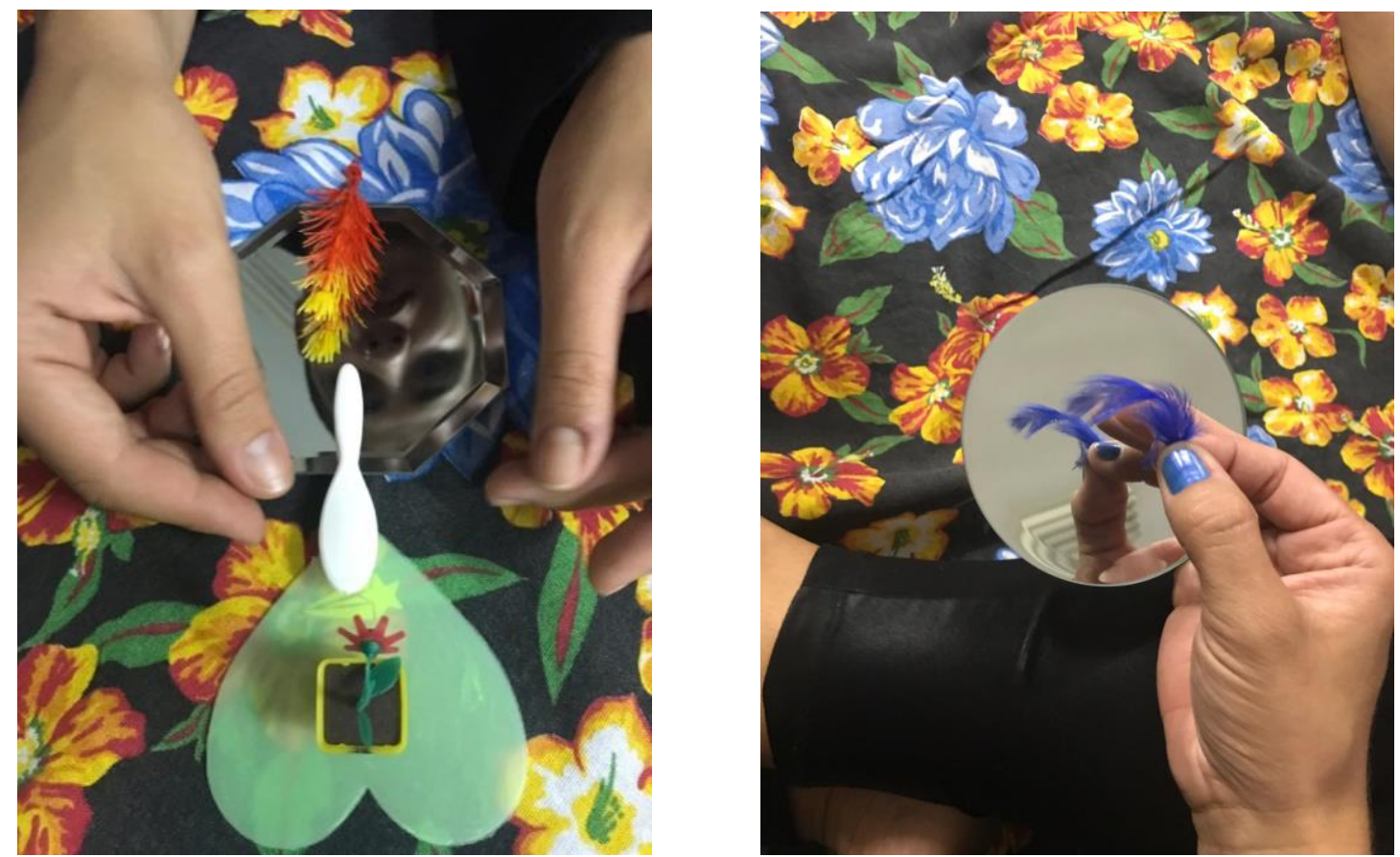

Foto: Lívia Lage.

Plataforma Pedagógica Sensitiva da aula - Da Cosmogênese à Célula - realizada em Julho de 2019 no Ateliê do Corpo/RJ e em Agosto de 2019 na Faculdade Angel Vianna/ RJ.

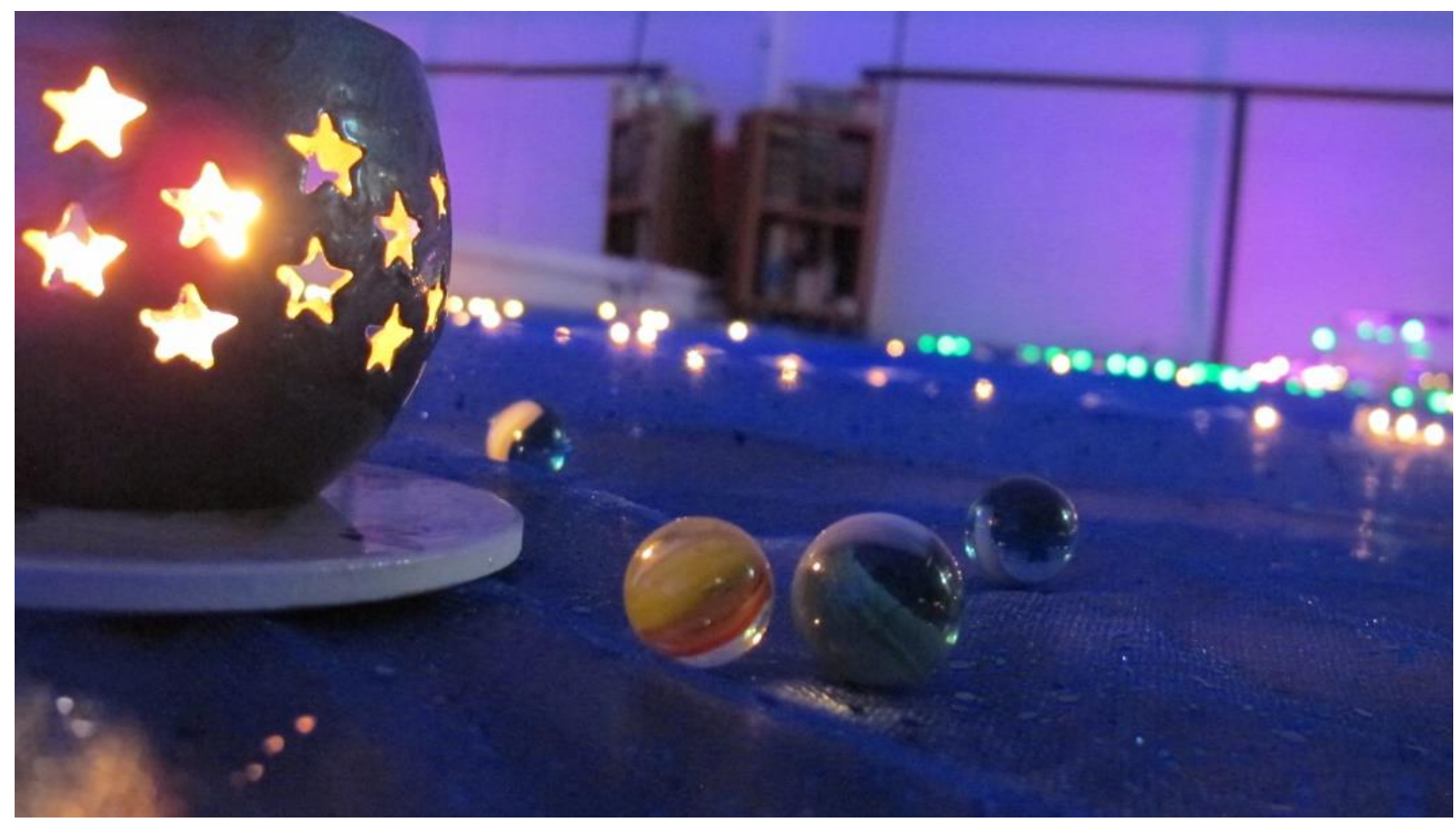

Foto: Lívia Lage.

Revista Interinstitucional Artes de Educar. Rio de Janeiro, V. 5, N.3- pág. 695-725 set-dez de 2019: "Educação: Corpo em movimento." - DOI: 10.12957/riae.2019.46727 


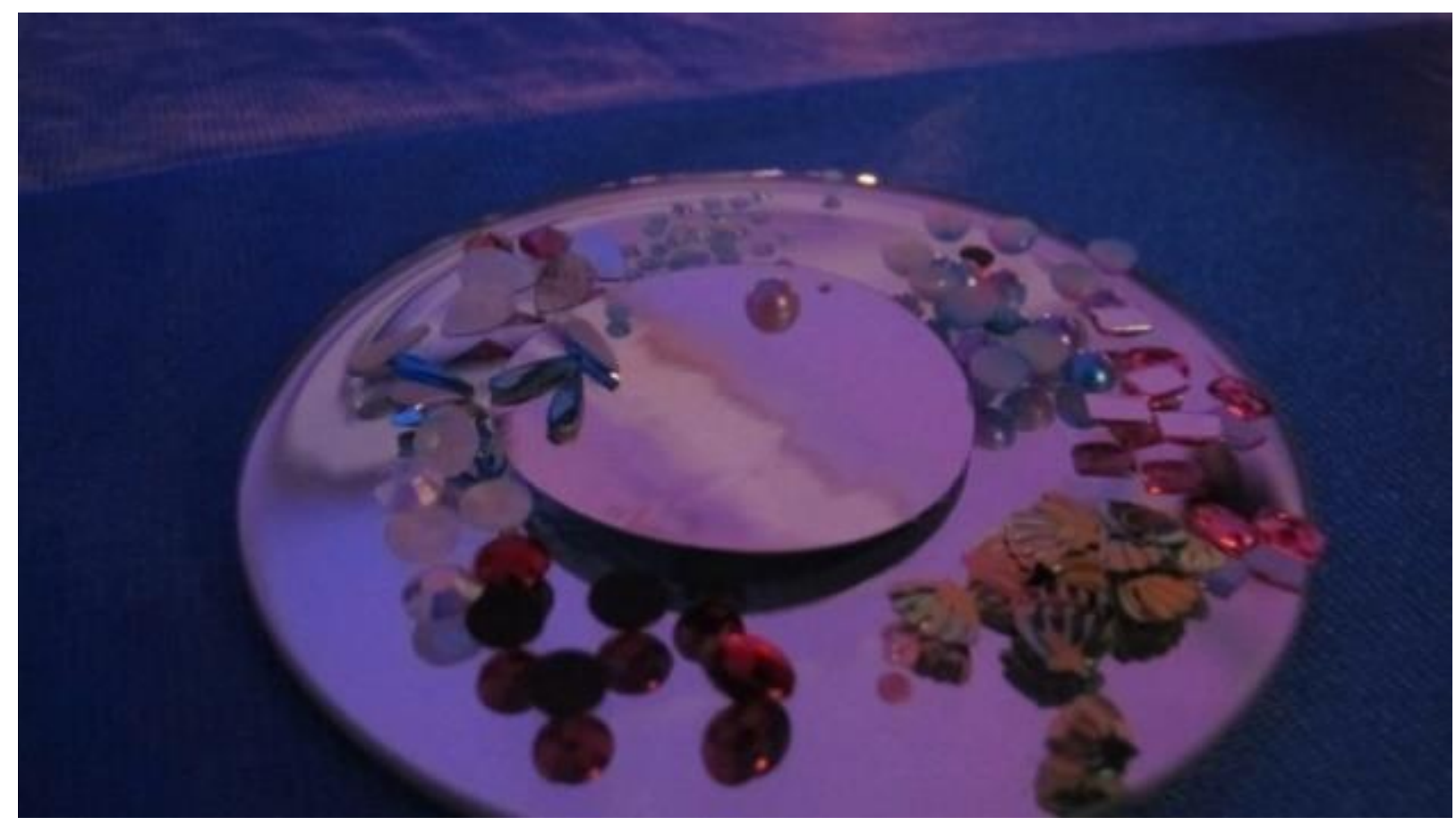

Fotos: Mary Cunha.

Plataforma Pedagógica Sensitiva da aula - Embriogênese - realizada em setembro de de 2019, no Ateliê do Corpo/RJ e na Faculdade Angel Vianna/RJ.
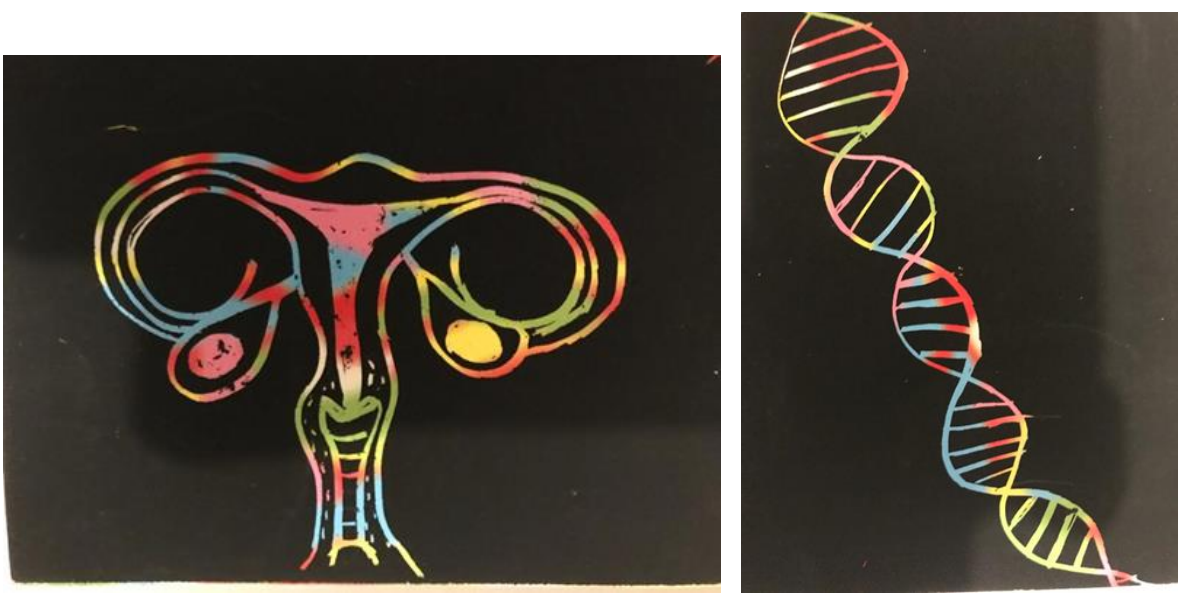

Revista Interinstitucional Artes de Educar. Rio de Janeiro, V. 5, N.3- pág. 695-725 set-dez de 2019: “Educação: Corpo em movimento." - DOI: 10.12957/riae.2019.46727 

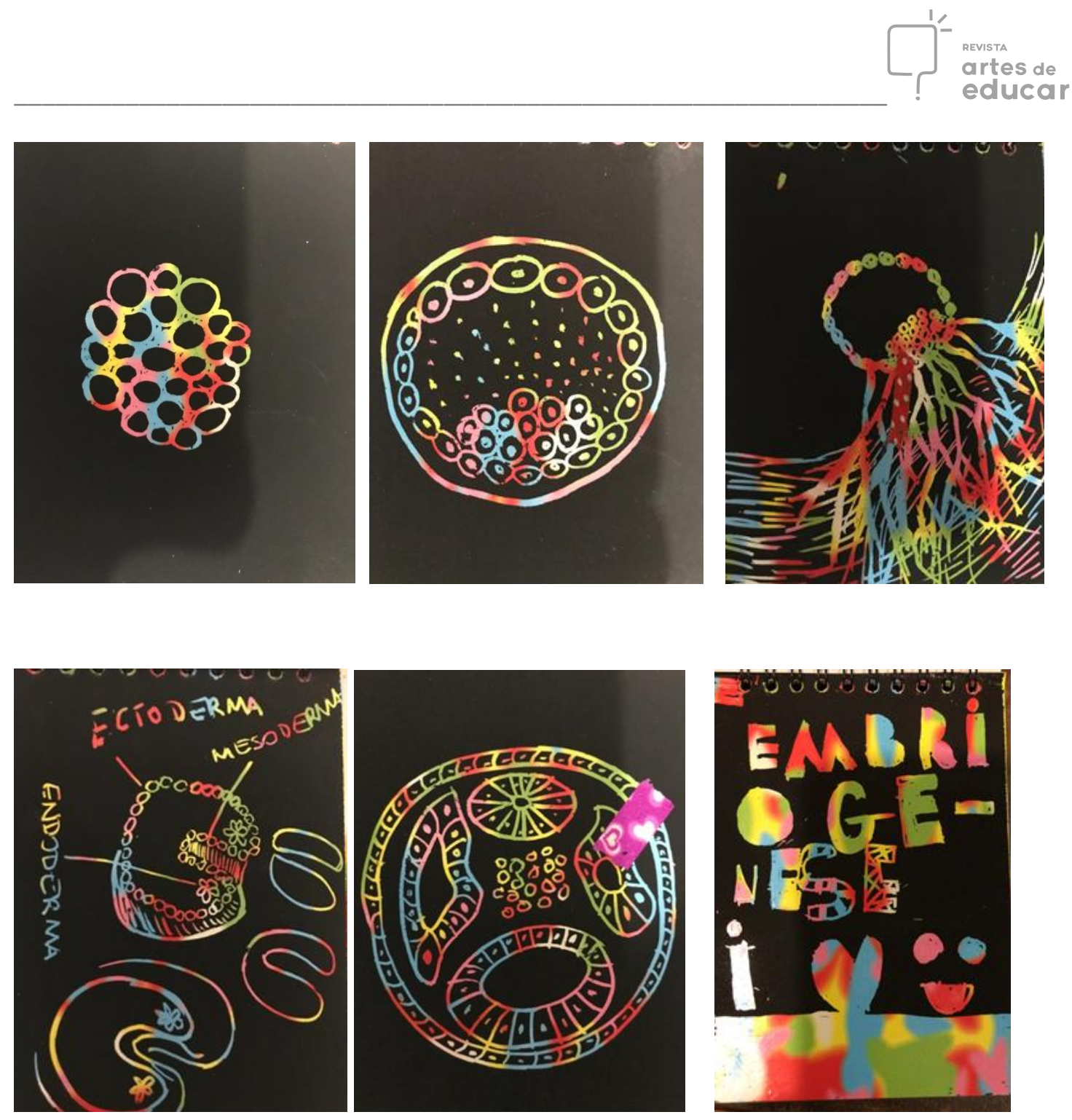

Fotos: Lívia Lage.

Plataforma Pegagógica Sensitiva - Ancestralidade: a Árvore da Vida - realizada em agosto de 2019 na Faculdade Angel Vianna/RJ.

Revista Interinstitucional Artes de Educar. Rio de Janeiro, V. 5, N.3-pág. 695-725 set-dez de 2019: “Educação: Corpo em movimento." - DOI: 10.12957/riae.2019.46727 


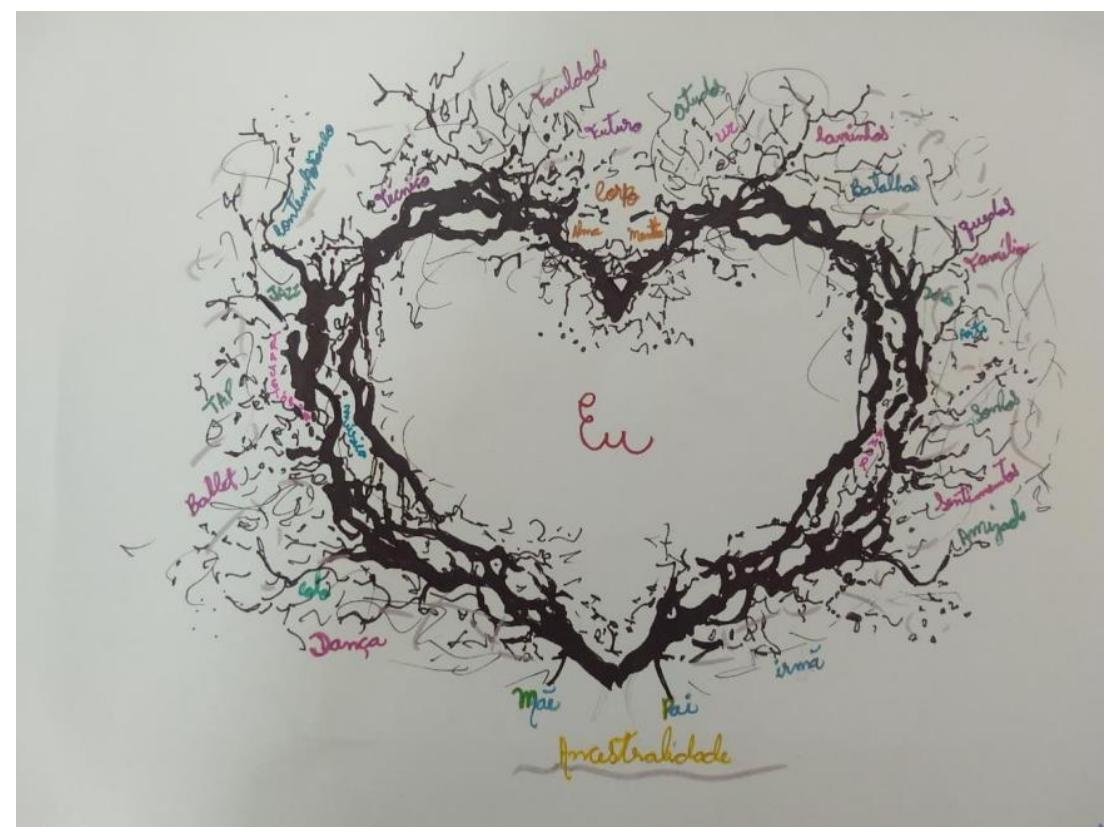

Foto: Rayanna Goulart.

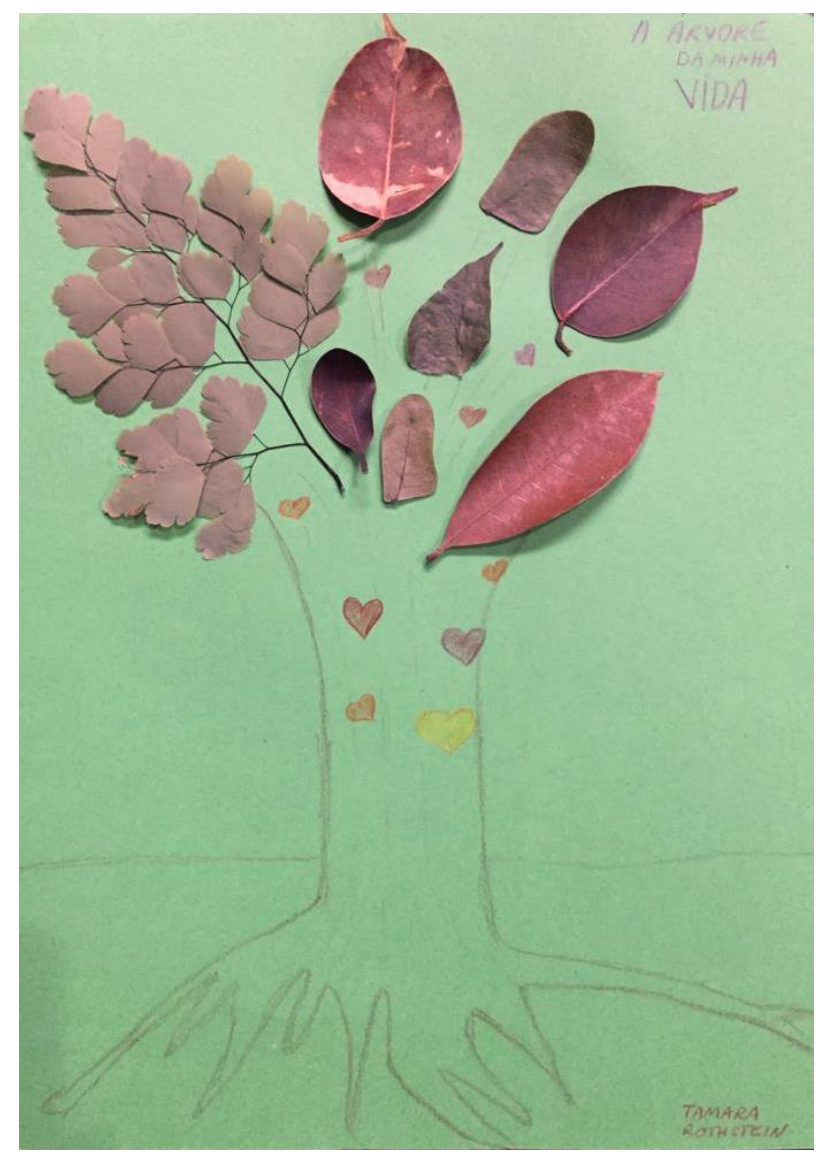

Foto: Tamara Ronstein.

\section{Considerações Finais}

Revista Interinstitucional Artes de Educar. Rio de Janeiro, V. 5, N.3- pág. 695-725 set-dez de 2019: "Educação: Corpo em movimento." - DOI: 10.12957/riae.2019.46727 


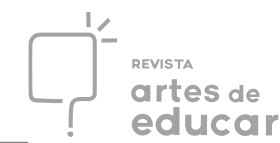

Neste primeiro momento cumpro o objetivo geral de apresentar a AnatomoPoesia, assim como contextualizar sua gênese, descrever a pesquisa e refletir por meio dos marcos teóricos sobre o embasamento do pensamento que alicerça a apresentação deste Relato de Experiência.

Cabe ressaltar que a AnatomoPoesia é uma pesquisa em andamento.

Na sua origem, a pesquisa foi pensada com intuito de ser prática pedagógica de educação pelo movimento, com o objetivo geral de integrar saberes. Tal objetivo foi definido com a intenção de compartilhar o espaço da sala de aula, fazendo deste espaço um lugar de encontro, apto a produzir sentido para a vida de todos os sujeitos envolvidos nessa relação, desenvolver experiências de responsabilidade e liberdade fundamentados no processo de ensinoaprendizagem, onde enriquecem em sabedoria estudantes e professores. Essa utopia tão necessária para manter a vida interior de um professor criativo seria possível de ser realizada?

Quanto às Plataformas Pedagógicas Sensitivas, sua função é incentivar o corpo do discente a que desenvolva conexão com as suas inteligências múltiplas. Isso pode acontecer? Como?

Ainda não posso responder a essas questões que eu mesma propus, considerando que estou no inicio de um caminho de pesquisa que se renova e se desdobra a cada passo, e mais experiências com grupos de estudantes e testes se seguirão, até que possa mensurar, ordenar, observar regularidades e daí qualificar as mesmas. Portanto, a pesquisa segue e em breve espero poder apresentar resultados mais aprimorados, com critérios e técnicas passíveis de revelar eficácia pedagógica.

\section{REFERÊNCIAS}

BOTELHO, Isaura et al. Entrevista com Angel Vianna. Revista Centro de Pesquisa e Formação Sesc São Paulo, p.270-279, 2016.

CAMPBELL, Linda et al. Ensino e aprendizagem por meio das Inteligências Múltiplas. Porto Alegre: Artmed, 2000.

GARDNER, Howard. Estruturas da Mente: A teoria das Inteligências Múltiplas. Porto Alegre: Editora Artes Médicas, 1994.

IMBASSAÍ, Maria Helena. Sensibilidade no cotidiano - Conscientização corporal. Rio de Janeiro: UAPÊ, 1996. 
LENT, Roberto. Cem bilhões de neurônios: Conceitos fundamentais de neurociência. São Paulo: Atheneu, 2010.

MANCUSO, Stefano. Revolução das Plantas. São Paulo: Ubu Editora, 2019.

MATURANA, Humberto e VARELA, Francisco. A árvore do conhecimento. Campinas: Workshpsy, 2001.

MELE, Claúdia. A produção de estados de presença através da Metodologia Angel

Vianna. Psicologia USU - Saberes e Questões. Vol.1, nº1, p.o1-21. Rio de janeiro, 2019.

MORIN, Edgar. A religação dos saberes: O desafio do século XXI. Rio de Janeiro: Editora Bertrand, 2002.

SALDANHA, Suzana. Angel Vianna: Sistema, método ou técnica? Rio de Janeiro: FUNARTE, 2009.

SALDANHA, Suzana. Angel Vianna: Sistema, método ou técnica? MAMBERTI, Sérgio. Angel Vianna: Sistema, método ou técnica? P.15. Rio de Janeiro: FUNARTE, 2009.

SALDANHA, Suzana. Angel Vianna: Sistema, método ou técnica? VIEIRA, Jorge. O método Angel Vianna é a ontologia sistêmica. P.33-35. Rio de Janeiro: FUNARTE, 2009.

STRAZZACAPPA, Márcia. A educação e a fábrica de corpos: a dança na escola. Cadernos Cedes, ano XXI, n53, p.69-83, abril 2001.

TEIXEIRA, Leticia. Inscrito em meu corpo: Uma abordagem reflexiva do trabalho corporal proposto por Angel Vianna. UNI-RIO. Programa de pós-graduação. Mestrado e doutorado em teatro. Dissertação de mestrado. Rio de Janeiro, 2008.

VIANNA, Klauss. A DANÇA. São Paulo: Summus, 2005.

\footnotetext{
' Formações: Bacharel em Teatro UNESA/RJ (2001). Licenciada em Dança Faculdade Angel Vianna/RJ (2009). Bacharel em Fisioterapia IBMR/RJ (2018). Especialista em Metodologia Angel Vianna - Faculdade Angel Vianna/RJ (2011). Especialista em Terapia através do Movimento - Faculdade Angel Vianna/RJ (2013). Terapeuta Floral (2005-2014).Atuação Profissional: Professora de Anatomia, Cinesiologia e Fisiologia aplicada à Dança na Faculdade Angel Vianna, desde 2017. Professora do Núcleo de Estudos Contemporâneos do Corpo (NECC)Contribuições Multiprofissionais da Dança /Faculdade Angel Vianna, RJ. Professora de Danças Circulares Meditativas no Curso Livre da Escola Angel Vianna e em Retiros, desde 2011. Fisioterapeuta e Terapeuta Floral. Artista/ Performer. RJ/Brasil. E-mail: anatomopoesia@gmail.com. ORCID https://orcid.org/0000-0002-1634$\underline{5770}$
} 